Jacek Jassem', Wojciech Biernat', Maciej Bryl2 , Joanna Chorostowska-Wynimko³, Rafał Dziadziuszko', Paweł Krawczyk ${ }^{4}$, Radzisław Kordek ${ }^{5}$, Dariusz M. Kowalski ${ }^{6}$, Maciej Krzakowski ${ }^{6}$, Włodzimierz Olszewski ${ }^{6}$, Tadeusz Orłowski ${ }^{3}$, Rodryg Ramlau², Witold Rzyman'

'Gdański Uniwersytet Medyczny

${ }^{2}$ Wielkopolskie Centrum Pulmonologii i Torakochirurgii w Poznaniu

${ }^{3}$ Instytut Gruźlicy i Chorób Płuc w Warszawie

${ }^{4}$ Uniwerystet Medyczny w Lublinie

${ }^{5}$ Uniwersytet Medyczny w Łodzi

${ }^{6}$ Centrum Onkologii — Instytut im. Marii Skłodowskiej-Curie w Warszawie

\title{
Rola systemowych metod leczenia u chorych na niedrobnokomórkowego raka płuca i złośliwego międzybłoniaka opłucnej: uaktualnione zalecenia ekspertów
}

The role of systemic therapies of non-small cell lung cancer and malignant pleural mesothelioma: updated expert recommendations

Przedruk z „Nowotwory Journal of Oncology” 2014; 64, 1: 61-75

\section{Abstract}

Lung cancer is the leading cause of cancer related death in Poland. About $85 \%$ of all lung cancer constitutes non-small cancer (NSCLC), in which the role of cytotoxic and molecularly targeted drugs is increasing. This article presents the current evidence-based recommendations for the use of these methods in clinical practice in NSCLC and malignant pleural mesothelioma.

Key words: non-small-lung cancer — treatment, pleural mesothelioma — treatment

Pneumonol. Alergol. Pol. 2014; 82: 133-149

\section{Streszczenie}

Rak płuca jest w Polsce najczęstszą przyczyną zgonów nowotworowych. Około 85\% wszystkich nowotworów płuca stanowi rak niedrobnokomórkowy (NDRP), w którym leki cytotoksyczne i ukierunkowane molekularnie odgrywają coraz większą rolę. W pracy przedstawiono oparte na obecnej wiedzy zalecenia dotyczące stosowania tych metod w praktyce klinicznej u chorych na NDRP oraz na złośliwego międzybłoniaka opłucnej.

Słowa kluczowe: rak płuca niedrobnokomórkowy — leczenie, międzybłoniak opłucnej — leczenie

Pneumonol. Alergol. Pol. 2014; 82: 133-149

\section{Wprowadzenie}

Mimo zmniejszającej się liczby osób palących tytoń rak płuca jest w Polsce nadal najczęstszą przyczyną zgonów nowotworowych wśród męż- czyzn i, od kilku lat, wśród kobiet. Rocznie umiera z tego powodu około 21000 osób [1]. Około $85 \%$ wszystkich nowotworów płuca stanowi rak niedrobnokomórkowy (NDRP), obejmujący raka płaskonabłonkowego, gruczołowego i wielko-

Adres do korespondencji: prof. dr hab. n. med. Jacek Jassem, Katedra i Klinika Onkologii i Radioterapii, GUMed, ul. Dębinki 7, 80-211 Gdańsk, e-mail: jjassem@gumed.edu.pl DOI: 10.5603/PiAP.2014.0019

Praca wpłynęła do Redakcji: 3.12.2013 r.

Copyright (C) 2014 PTChP

ISSN 0867-7077 
komórkowego. Wśród nich w ostatnich latach w wielu krajach na pierwsze miejsce wysuwa się rak gruczołowy. Resekcja miąższu płucnego pozostaje główną metodą leczenia NDRP we wczesnych stadiach nowotworu (stopień I, II i wybrane przypadki w stopniu IIIA), ale do zabiegu kwalifikuje się jedynie około 15-20\% ogółu chorych na NDRP. Udział pięcioletnich przeżyć po leczeniu operacyjnym wynosi, w zależności od stopnia zaawansowania, od 20 do ponad $80 \%$ [2-5], a najczęstszą formą niepowodzenia jest rozsiew nowotworu.

Systemowe metody leczenia: chemioterapia i leki ukierunkowane molekularnie ogrywają istotną rolę w leczeniu chorych na NDRP. Z uwagi na szybki rozwój wiedzy na temat biologii i kliniki tego nowotworu istnieje stała potrzeba aktualizacji klinicznych zaleceń dotyczących stosowania tych metod. Obecne opracowanie jest kontynuacją podobnych zaleceń publikowanych w poprzednich latach [5-7]. Oprócz NDRP zalecenia te dotyczą również złośliwego międzybłoniaka opłucnej, którego częstość stopniowo wzrasta w większości krajów Europy. Nie uwzględniają one natomiast drobnokomórkowego raka płuca (DRP), bowiem systemowe leczenie tego nowotworu pozostaje bez istotnych zmian w ciągu ostatnich dekad.

Tak jak poprzednio w obecnym opracowaniu znalazł się rozdział dotyczący badań patomorfologicznych, bowiem ich wynik w coraz większym stopniu decyduje o wyborze rodzaju systemowego leczenia. W obecnym dokumencie znacznie rozszerzono część dotyczącą leków ukierunkowanych molekularnie, które w NDRP w dużym stopniu zaczynają zastępować tradycyjne leki cytotoksyczne.

Przedstawiony dokument stanowi wspólne stanowisko grupy ekspertów w dziedzinie onkologii, torakochirurgii, patomorfologii i pneumonologii i opiera się na wiedzy dostępnej w listopadzie 2013 roku.

\section{Diagnostyka patomorfologiczna nowotworów płuca i opłucnej}

Podstawą rozpoznania raka płuca pozostaje badanie mikroskopowe materiału cytologicznego lub histologicznego. Materiałem do badania cytologicznego może być plwocina, wymaz z oskrzela, popłuczyny oskrzelowe i aspiraty uzyskane drogą biopsji cienkoigłowej przez ścianę klatki piersiowej lub przez ścianę oskrzela. Materiał cytologiczny można również zabezpieczać w postaci bloczków parafinowych („,cytobloki”). W przypadkach guzów zlokalizowanych centralnie zaleca się pobrać wymazy oskrzelowe $\mathrm{w}$ trakcie bronchofiberoskopii, a metodą $\mathrm{z}$ wyboru w guzach zlokalizowanych obwodowo jest transtorakalna biopsja aspiracyjna cienkoigłowa lub biopsja gruboigłowa. Pobranie plwociny do badania mikroskopowego w przypadku podejrzenia nowotworu płuca znajduje zastosowanie tylko u chorych, u których nie można wykonać bronchofiberoskopii lub biopsji przez ścianę klatki piersiowej. Czułość badania plwociny jest ograniczona, zwłaszcza w guzach położonych obwodowo.

Ustalone kryteria cytomorfologiczne pozwalają na wiarygodne rozpoznanie raka płuca, jak też na różnicowanie DRP i NDRP. Rozróżnienie pomiędzy rakiem gruczołowym i płaskonabłonkowym, szczególnie w postaciach wysokodojrzałych, nie stwarza trudności. Nawet jeśli NDRP jest rozpoznawany na podstawie badania materiału cytologicznego, należy także określić typ histologiczny (jest to możliwe w badaniu standardowym $\mathrm{z}$ barwieniem hematoksyliną i eozyną w około 75\% przypadków). W ocenie materiału cytologicznego powinno się rutynowo stosować barwienia immunocytochemiczne z udziałem panelu przeciwciał. Ponieważ w materiale cytologicznym często uszkodzona jest cytoplazma, zaleca się stosowanie przeciwciał, które cechuje reakcja jądrowa, np. TTF1 i p63 lub p40 [8].

Ocena preparatów histologicznych jest standardową metodą rozpoznawania nowotworów, w tym raka płuca. W przypadkach guzów zlokalizowanych centralnie zazwyczaj są to wycinki pobrane w czasie bronchofiberoskopii. Ocena mikroskopowa takiego materiału pozwala nie tylko na rozpoznanie nowotworu, ale również na dokładne określenie typu histologicznego, co ma istotne znaczenie $\mathrm{w}$ wyborze metody leczenia.

Do niedawna istotą przedoperacyjnego rozpoznania raka płuca, zarówno u chorych kwalifikujących, jak i niekwalifikujących się do zabiegu, było odróżnienie DRP od NDRP. Postępy w systemowym leczeniu NDRP i wprowadzenie leków nowych generacji stworzyły jednak sytuację, w której także rozpoznanie typu NDRP staje się istotne w wyborze systemowego leczenia. Wiadomo np., że pemetreksed wykazuje większą aktywność w gruczolakorakach niż w rakach płaskonabłonkowych, a mutacje genu EGFR (epidermal growth factor receptor) czy rearanżacje genu ALK (anaplastic lymphoma kinase), które stanowią cele terapii ukierunkowanych molekularnie, bardzo rzadko występują w rakach płaskonabłonkowych.

W rozpoznawaniu głównych typów NDRP podstawowym kryterium pozostaje ocena mor- 
fologii guza, natomiast dyskusyjna jest rola immunohistochemii [9-16]. Metoda ta może być natomiast pomocna w ocenie z drobnych wycinków. Najczęściej wykorzystywanymi markerami, które pozwalają na odróżnienie gruczolakoraka od raka płaskonabłonkowego płuca, są TTF-1, cytokeratyna (CK) 34betaE12, CK 5 i CK 7, białko p63, napsyna A oraz białko p40. Żaden z nich nie jest jednak swoisty dla określonego typu NDRP i często wykazuje ekspresję różnego stopnia zarówno w rakach płaskonabłonkowych, jak i gruczołowych [17]. W efekcie, pomimo zastosowania całego panelu wspomnianych markerów immunohistochemicznych wraz z barwieniem na obecność śluzu, nie zawsze można jednoznacznie ustalić rozpoznanie histopatologiczne. W przypadku niejednoznacznego obrazu morfologicznego i jednoczesnej ekspresji markerów sugerujących różnicowanie gruczołowe zaproponowano określenie „rak niedrobnokomórkowy morfologicznie i immunofenotypowo odpowiadający gruczolakorakowi” (NSCLC - favor adenocarcinoma) $[18,19]$. Z kolei w przypadku niejednoznacznych cech histologicznych raka płaskonabłonkowego i równoczesnej obecności fenotypu tego guza stosowany jest termin „rak niedrobnokomórkowy morfologicznie i immunofenotypowo odpowiadający rakowi płaskonabłonkowemu" (NSCLC - favor squamous cell carcinoma) [18, 19]. Brak morfologicznych i fenotypowych cech raka płaskonabłonkowego, gruczolakoraka i raka neuroendokrynnego jest wskazaniem do postawienia rozpoznania „rak niedrobnokomórkowy o nieustalonym typie” [NSCLC, not otherwise specified $(N O S)][18,19]$. Nie zaleca się natomiast rozpoznawania raka wielkokomórkowego na podstawie materiału oligobiopsyjnego, ponieważ w takich przypadkach w materiale pooperacyjnym często bezspornie rozpoznaje się raka płaskonabłonkowego lub gruczołowego. Około 25\% raków płuca wykazuje mieszane utkanie pod względem typu histologicznego.

Najbardziej miarodajne pod względem określenia typu histologicznego NDRP oraz ewentualnej heterogenności nowotworu jest patomorfologiczne badanie usuniętych tkanek, jednak do resekcji kwalifikuje się jedynie 15-20\% chorych. Diagnostyka pooperacyjna raka płuca opiera się na kryteriach zawartych w klasyfikacji Światowej Organizacji Zdrowia (WHO) z 2004 roku [20]. Uzupełnia ją nowa klasyfikacja gruczolakoraka płuca, opracowana pod auspicjami International Association for the Study of Lung Cancer (IASLC), American Thoracic Society (ATS) oraz European Respiratory Society (ERS) [19]. Zrezygnowano z definicji raka pęcherzykowo-oskrzelikowego i wprowadzono całe spektrum rozrostów, od nieinwazyjnego gruczolakoraka (adenocarcinoma-in-situ - AIS) poprzez minimalnie inwazyjnego gruczolakoraka (minimally invasive adenocarcinoma - MIA) do inwazyjnego gruczolakoraka (ze wzrostem napełzającym). Podtyp śluzowy raka pęcherzykowo-oskrzelikowego zmieniono na inwazyjny typu gruczolakoraka śluzowego (invasive mucinous adenocarcinoma). Istotnym uzupełnieniem rozpoznania gruczolakoraka płuca jest uściślenie podtypów morfologicznych, które wchodzą w skład guza. Ma to znaczenie rokownicze, ponieważ np. gruczolakoraki o litej i mikrobrodawkowej budowie są bardziej, a gruczolakoraki z przewagą komponentu tapetującego (lepidic component) - mniej agresywne [19]. Zalecenia grupy roboczej IASLC/ATS/ERS nakazują ilościowe określanie obecności wszystkich komponentów guza (z oceną w przedziałach 5-procentowych), wskazując komponent determinujący histologiczną złośliwość nowotworu.

Dodatkowym argumentem przemawiającym za uwzględnianiem w rozpoznaniu histopatologicznym określenia podtypu gruczolakoraka jest względnie częsta obecność mutacji genu EGFR w postaciach dobrze zróżnicowanych, zwłaszcza z przewagą wzrostu napełzającego/tapetującego. Ułatwia to kwalifikowanie gruczolakoraków do molekularnej diagnostyki. Barwienie immunohistochemiczne w kierunku ekspresji EGFR nie wnosi istotnych informacji diagnostyczno-terapeutycznych, gdyż ekspresja białka EGFR nie jest wystarczająco czułym i swoistym wyznacznikiem w doborze chorych do leczenia inhibitorami szlaku EGFR. Czynnikiem kwalifikującym do tej formy leczenia nie jest również zwiększona liczba kopii genu EGFR. Obecność aktywującej mutacji genu EGFR, jedynego uznanego czynnika predykcyjnego do leczenia inhibitorami EGFR, należy określać w materiale tkankowym. Ocena w materiale cytologicznym jest możliwa, przy czym jest ona nieco łatwiejsza przy użyciu tzw. cytobloków. Wartość oceny mutacji genu EGFR w surowicy jest nadal przedmiotem badań. Istotnym zadaniem patomorfologa jest wybór odpowiednich fragmentów wycinków tkankowych do badania genu EGFR. Analizę molekularną można bowiem przeprowadzić w wycinkach zawierających odpowiedni odsetek komórek nowotworowych w stosunku do tkanek nienowotworowych.

Diagnostyka tkankowa wycinków z raka płuca dotyczy także identyfikacji innych zaburzeń molekularnych, które mogą stanowić potencjalny cel terapii. Należy do nich translokacja genu $A L K$, 
który w tym nowotworze tworzy najczęściej gen fuzyjny z EML4 (echinoderm microtubule-associated protein-like 4). Obecność rearanżacji tego genu określa się metodą FISH z zastosowaniem sondy break-apart, umożliwiającej wykrycie także jego alternatywnych translokacji. Wstępną, ale dość czułą metodą jest identyfikacja ekspresji białka ALK badaniem immunohistochemicznym [21, 22]. Inne, rzadkie zaburzenia molekularne w raku płuca (np. genu ROS1) mogą być także wykrywane w zabezpieczonych w postępowaniu patomorfologicznym wycinkach nowotworu [23].

$\mathrm{W}$ diagnostyce patomorfologicznej NDRP należy uwzględnić wymogi techniczne metod molekularnej diagnostyki zaburzeń występujących w tym nowotworze. Jeśli dostępny jest jedynie materiał o niewielkiej objętości, zalecane jest sporządzenie już w czasie pierwotnej diagnostyki patomorfologicznej 10 preparatów, z których 2 będą wykorzystane do standardowej diagnostyki, 2 - do ewentualnych badań immunohistochemicznych, a kolejnych 6 - do ewentualnych badań genetycznych (w dwóch ostatnio wymienionych metodach niezbędne jest użycie szkiełek podstawowych zwiększających przyleganie skrawków, np. silanizowanych). Nieodzowna $\mathrm{w}$ tym procesie jest bliska współpraca patologa z genetykiem klinicznym. Zapewnia ona analizę materiału zawierającego odpowiednio reprezentatywny materiał tkankowy (liczne komórki nowotworowe z niewielką domieszką tkanek podścieliska, martwicy, odczynu zapalnego itp.) oraz umożliwia optymalizacje procesu diagnostyki genetycznej. Całość tego procesu powinna być przedmiotem niezależnej, zewnętrznej oceny i skutkować uzyskiwaniem certyfikacji jednostek wykonujących te badania.

Diagnostyka patomorfologiczna międzybłoniaka powinna się opierać na badaniu histologicznym. Materiał cytologiczny w międzybłoniaku, uzyskiwany najczęściej drogą aspiracji płynu wysiękowego z opłucnej, zawiera liczne komórki epitelioidalne tego nowotworu, jednak ich odróżnienie od łagodnych komórek międzybłonka wykazujących odczynową atypię może być niekiedy bardzo trudne lub niemożliwe. Ponadto w odróżnieniu od raka płuca istotnym uzupełnieniem badania morfologicznego jest określenie immunofenotypu (obecnie rzadziej cech ultrastrukturalnych), co umożliwia ustalenie jednoznacznego rozpoznania. $Z$ tego powodu rozpoznanie złośliwego międzybłoniaka opłucnej powinno się opierać na ocenie materiału tkankowego, pozwalającej dodatkowo ocenić naciekanie podścieliska [24]. Metodą z wyboru w diagno- styce międzybłoniaka opłucnej jest pobranie licznych wycinków na drodze wideotorakoskopii.

Określenie immunofenotypu nowotworu rozrastającego się w opłucnej pozwala na jednoznaczne rozpoznanie międzybłoniaka, a w szczególności na różnicowanie międzybłoniaka i rzekomomiędzybłoniakowego raka płuca (pseudomesotheliomatous adenocarcinoma). $\mathrm{W}$ tym celu konieczna jest ocena ekspresji przynajmniej dwóch markerów typowych dla międzybłoniaka [kalretynina, cytokeratyna 5/6, HBME-1, produkt genu guza Wilmsa (Wilms tumor 1, WT1)] i przynajmniej dwóch charakterystycznych dla raka (tarczycowego czynnika transkrypcyjnego 1 - TTF1, antygenu rakowo-płodowego - CEA, BerEP4, CD15 itp.) [25]. Obraz histologiczny należy rozpatrywać w powiązaniu z obrazem klinicznym (badanie wideotorakoskopowe, badania obrazowe). Obecność guzków i/lub guzowatego pogrubienia opłucnej zwiększa prawdopodobieństwo złośliwego charakteru zmian, a nieobecność tych cech nakazuje ostrożność w postawieniu rozpoznania międzybłoniaka [26].

\section{Przedoperacyjna chemioterapia}

Przedoperacyjna (indukcyjna) chemioterapia była przedmiotem kilku badań III fazy, których wyniki były rozbieżne [27-32]. W większości badań obserwowano względnie wysoki odsetek obiektywnych odpowiedzi, a w kilku — także wydłużenie czasu przeżycia wolnego od nawrotu lub czasu całkowitego przeżycia. W większości badań udawało się w pełni zrealizować zaplanowaną przedoperacyjną chemioterapię, ale jednocześnie wiązała się ona z niewielkim zwiększeniem ryzyka pooperacyjnych powikłań. Zbiorcza analiza 13 badań III fazy opublikowanych do 2010 roku (łącznie 3224 chorych) wykazała, że zastosowanie przedoperacyjnej chemioterapii pozwala uzyskać zmniejszenie względnego ryzyka zgonu o 14\% [33].

Porównanie skuteczności przed- i pooperacyjnej chemioterapii jest trudne. W jedynym, względnie niewielkim badaniu III fazy porównującym bezpośrednio obie te metody wykazano ich podobną skuteczność [34]. Istotnych różnic nie wykazała także zbiorcza analiza wyników badań klinicznych z udziałem obu metod [35]. Należy jednak podkreślić, że w badaniach z zastosowaniem pooperacyjnej chemioterapii uczestniczyło łącznie więcej chorych, zatem ich dowodowa wartość jest większa.

W dotychczasowych badaniach przedoperacyjną chemioterapię (lub radiochemioterapię) stosowano najczęściej u chorych w stopniu IIIA, z cechą N2. Strategia leczenia w tej grupie jest na- 
dal przedmiotem kontrowersji, bowiem w dwóch dużych badaniach III fazy nie wykazano wyższości leczenia operacyjnego nad radykalną radioterapią lub radiochemioterapią [36, 37]. W innym badaniu wykazano podobną skuteczność przedoperacyjnej radiochemioterapii i przedoperacyjnej chemioterapii [38].

Wyniki badań bez losowego doboru chorych wskazują, że zastosowanie przedoperacyjnej chemioterapii w skojarzeniu z napromienianiem jest uzasadnione w przypadku lokalizacji nowotworu w szczycie płuca (guz Pancoasta) [39-41]. We wcześniejszych badaniach w przedoperacyjnej radiochemioterapii stosowano dawki w granicach 45-50 Gy, ale nowsze doniesienia wskazują, że bezpiecznie można zastosować wyższą dawkę [40].

\section{Zalecenia}

Wyniki dotychczasowych badań, w których oceniano skuteczność przedoperacyjnej chemioterapii, są niejednoznaczne. Metodę tę można rozważać u wybranych chorych w stopniu klinicznego zaawansowania IIIA (cecha pN2), będących potencjalnymi kandydatami do doszczętnej resekcji miąższu płucnego. Przed rozpoczęciem leczenia należy dokładnie ocenić zaawansowanie nowotworu przy użyciu mediastinoskopii i/ lub badania pozytonowej emisyjnej tomografii (PET). Przedoperacyjna chemioterapia powinna obejmować 2-3 cykle dwulekowego schematu zawierającego pochodną platyny w połączeniu z jednym z leków trzeciej generacji (gemcytabina, winorelbina, paklitaksel lub docetaksel). Do resekcji miąższu płucnego mogą być kwalifikowani wyłącznie chorzy z całkowitą odpowiedzią w obrębie węzłów chłonnych śródpiersia, potwierdzoną w mediastinoskopii. Przedoperacyjna chemioterapia w skojarzeniu z radioterapią pozostaje rutynowym postępowaniem u chorych z lokalizacją raka w szczycie płuca (guz Pancoasta).

Decyzję o zastosowaniu przedoperacyjnej chemioterapii lub radiochemioterapii i dalszym leczeniu (chirurgia, radiochemioterapia lub wyłączna radioterapia) powinien zawsze podejmować wielospecjalistyczny zespół. Metody te mogą być stosowane wyłącznie w ośrodkach dysponujących pełnymi możliwościami nowoczesnej diagnostyki i wielodyscyplinarnego leczenia raka płuca.

\section{Pooperacyjna chemioterapia}

Wyniki badań III fazy, w których stosowano pooperacyjną chemioterapię z udziałem pochodnych platyny, są sprzeczne [42-49], niemniej w kilku z nich uzyskano wyższe o 4-15\% wskaźniki pięcioletniego przeżycia [45, 46, 49]. W kilku dużych badaniach analiza późnych wyników nie potwierdziła jednak opisywanych wcześniej korzyści z leczenia [47, 50, 52].

Obecnie w pooperacyjnej chemioterapii najczęściej stosuje się 3-4 cykle dwulekowej chemioterapii zawierającej pochodną platyny i winorelbinę lub paklitaksel, przy czym dowody o najwyższym stopniu wiarygodności dotyczą wyłącznie skojarzenia cisplatyny i winorelbiny (dwa pozytywne badania; bezwzględna różnica $w$ prawdopodobieństwie pięcioletniego przeżycia odpowiednio 15\% i 9\%) [46, 49].

Pięć największych badań klinicznych, obejmujących łącznie 4584 chorych, w których stosowano schematy oparte na cisplatynie [43-46, 49], poddano metaanalizie Lung Adjuvant Cisplatin Evaluation (LACE) [52]. W analizie tej udział pięcioletnich przeżyć u chorych otrzymujących pooperacyjną chemioterapię był o $5 \%$ wyższy w porównaniu z wyłączną resekcją, przy czym $\mathrm{w}$ analizie podgrup korzyść dotyczyła wyłącznie chorych w stopniach zaawansowania II i IIIA. Stosowanie chemioterapii u chorych w stopniu IB nie przyniosło znamiennej korzyści (z wyjątkiem guzów o średnicy większej niż $4 \mathrm{~cm}$ ), a u chorych w stopniu IA stwierdzono wręcz nieznamiennie gorsze wyniki. Niekorzystny wpływ na wyniki pooperacyjnej chemioterapii miał niższy stopień sprawności (stopień 2. według klasyfikacji WHO), natomiast inne czynniki (wiek, płeć i typ histologiczny nowotworu) nie miały istotnego znaczenia.

Podobną korzyść wykazała aktualizacja metaanalizy Non-Small Cell Lung Cancer Collaborative Group, obejmującej 30 badań klinicznych III fazy z udziałem 8147 chorych [53]. Korzyść ta była niezależna od wieku, płci oraz typu histologicznego nowotworu. Zastosowanie uzupełniającej chemioterapii w grupie chorych, którzy otrzymali dodatkowo pooperacyjną radioterapię (12 badań - 2660 chorych), zwiększało o 4\% wskaźnik 5-letniego przeżycia.

W przeprowadzonych badaniach klinicznych u 10-40\% chorych obserwowano niepożądane działania w stopniu 3.-4., a ponad 30\% chorych nie ukończyło zaplanowanego leczenia. Toksyczne działania dotyczyły najczęściej układu krwiotwórczego i pokarmowego. Leczenia względnie częściej nie można było w pełni zrealizować u chorych w wieku powyżej 70 lat, u kobiet oraz u chorych poddanych pneumonektomii [53].

W ostatnich latach podejmowano liczne próby znalezienia biologicznych czynników rokowniczych i predykcyjnych, które ułatwiałyby dobór chorych do pooperacyjnej chemioterapii 
oraz wybranie najbardziej skutecznego schematu. Żaden z tych czynników nie przeszedł jednak pozytywnej walidacji w prospektywnym badaniu klinicznym i nie znalazł zastosowania w rutynowym postępowaniu.

\section{Zalecenia}

Pooperacyjna chemioterapia powinna być stosowana u chorych na NDRP spełniających następujące kryteria:

- pełne pooperacyjne badanie patomorfologiczne (pTNM);

- $\quad$ stopień zaawansowania pII-IIIA ustalony na podstawie pooperacyjnego badania patomorfologicznego;

- doszczętna resekcja miąższu płucnego z anatomicznym wycięciem węzłów chłonnych grupy N1 oraz całkowitym lub próbnym wycięciem węzłów grupy N2;

- dobry stan sprawności;

- brak współistniejących poważnych chorób zwiększających ryzyko wystąpienia niepożądanych działań;

- zachowana wydolność ważnych narządów;

- pełna rekonwalescencja po resekcji płucnej.

Chemioterapię należy rozpocząć w ciągu pierwszych 7 tygodni od zabiegu operacyjnego. Powinna ona obejmować 3-4 cykle dwulekowego schematu zawierającego pochodną platyny, przy czym preferowane jest skojarzenie cisplatyny w dawce $80-100 \mathrm{mg} / \mathrm{m}^{2} \mathrm{z}$ winorelbiną.

\section{Chemioterapia w skojarzeniu $\mathrm{z}$ radioterapią $\mathbf{w}$ miejscowo zaawansowanym i nieoperacyjnym NDRP}

U większości chorych na NDRP nowotwór wykrywany jest w stadium miejscowego zaawansowania (stopień III), w którym na ogół wykonanie doszczętnej resekcji miąższu płucnego nie jest możliwe. W tej grupie chorych najczęściej stosuje się radioterapię, ale pozwala ona uzyskać jedynie około $10 \%$ pięcioletnich przeżyć. Tak złe wyniki są spowodowane wysokim udziałem zarówno nawrotów miejscowo-regionalnych, jak i odległych. Niezależnie od tego przyczyną wielu zgonów w tej grupie są współistniejące choroby, związane głównie z wieloletnim narażeniem na dym tytoniowy.

Skojarzenie radioterapii z chemioterapią ma w założeniu poprawić miejscową kontrolę nowotworu w klatce piersiowej oraz obniżyć ryzyko krwiopochodnego rozsiewu [54]. W miejscowo zaawansowanym NDRP stosowano kilka strategii kojarzenia chemioterapii i radioterapii: chemioterapię poprzedzającą radioterapię (indukcyjną), stosowaną po zakończeniu radioterapii (konsolidującą), równoczesną z radioterapią oraz ich kombinacje. Spośród nich kliniczne zastosowanie znalazły indukcyjna chemioterapia i równoczesna radiochemioterapia.

W latach 80. i 90. ubiegłego wieku przeprowadzono kilka dużych badań klinicznych z randomizacją, które wykazały wydłużenie czasu całkowitego przeżycia pod wpływem chemioterapii stosowanej zarówno przed, jak i w trakcie radioterapii [55-58]. Wyższość skojarzonego leczenia nad wyłączną radioterapią potwierdzono także w dwu metaanalizach [59,60].

W indukcyjnej chemioterapii najczęściej stosuje się standardowe dwulekowe schematy zawierające cisplatynę lub karboplatynę w skojarzeniu z winorelbiną, taksoidami (paklitaksel, docetaksel) lub gemcytabiną, natomiast w równoczesnej radiochemioterapii - dwulekowe schematy zawierające cisplatynę w skojarzeniu $\mathrm{z}$ etopozydem, winorelbiną lub taksoidami.

Wyniki kilku badań z randomizacją [61-63] i metaanalizy $[64,65]$ wskazują, że chemioterapia stosowana równocześnie $\mathrm{z}$ radioterapią, $\mathrm{w}$ porównaniu z indukcyjną chemioterapią, pozwala uzyskać o kilka procent wyższy odsetek pięcioletnich przeżyć. Metoda ta związana jest jednak z kilkakrotnie wyższym ryzykiem ostrego popromiennego zapalenia przełyku w stopniu 3. i 4. [64]. Niezależnie od tego ponad połowa chorych na miejscowo zaawansowanego NDRP nie kwalifikuje się do tej formy agresywnego leczenia z powodu zaawansowanego wieku, złego stanu ogólnego, ubytku masy ciała lub współwystępujących chorób [66]. W równoczesnej radiochemioterapii stosuje się standardowe dawki promieniowania (60-66 Gy) przy konwencjonalnym frakcjonowaniu (5 dawek po $2 \mathrm{~Gy}$ w ciągu tygodnia), bowiem próby jej eskalacji powyżej 70 Gy zakończyły się niepowodzeniem [67]. Nie wykazano również wyższości napromieniania hiperfrakcjonowanego w porównaniu z konwencjonalnym [63].

W przypadku indukcyjnej chemioterapii krytycznym czynnikiem warunkującym skuteczność leczenia jest czas od zakończenia chemioterapii do rozpoczęcia radioterapii, bowiem pod wpływem chemioterapii dochodzi do przyspieszonej repopulacji komórek nowotworowych [68]. Dodanie indukcyjnej lub konsolidującej chemioterapii do równoczesnej radiochemioterapii nie ma wpływu na czas przeżycia, a równocześnie zwiększa toksyczność leczenia [69, 70]. Niepowodzeniem zakończyły się także próby kojarzenia radiochemioterapii z gefitynibem [71] i przeciwciałem monoklonalnym anty-EGFR — cetuksymabem [72]. 
Wybierając metodę leczenia chorych na miejscowo zaawansowanego nieoperacyjnego NDRP należy pamiętać, że w badaniach klinicznych, które wytyczają standardy postępowania, uczestniczą na ogół chorzy w dobrym stanie sprawności, z ograniczoną wielkością guza w klatce piersiowej i bez znacznego ubytku masy ciała. W rzeczywistości wielu chorych nie spełnia tych kryteriów i należy u nich zastosować mniej agresywne metody leczenia. Niezależnie od tego bezwzględna korzyść kliniczna związana ze stosowaniem chemioterapii $\mathrm{w}$ skojarzeniu $\mathrm{z}$ radioterapią pozostaje niewielka.

\section{Zalecenia}

U chorych na miejscowo zaawansowanego NDRP, którzy nie kwalifikują się do resekcji miąższu płucnego, postępowaniem z wyboru jest skojarzenie radioterapii z równoczesną chemioterapią zawierającą cisplatynę z etopozydem lub winorelbiną. $Z$ powodu znacznego nasilenia ostrej toksyczności płucnej w równoczesnej radiochemioterapii nie stosuje się schematów zawierających gemcytabinę. Należy dążyć do podania pełnych dawek radioterapii (60-66 Gy) i chemioterapii. Z uwagi na zwiększoną toksyczność równoczesną radiochemioterapię można stosować wyłącznie u chorych w dobrym stanie sprawności, bez znaczącego ubytku masy ciała, z prawidłowymi wskaźnikami wydolności oddechowej oraz ograniczonym zasięgiem nowotworu w klatce piersiowej. Metoda ta może być stosowana wyłącznie w specjalistycznych ośrodkach dysponujących możliwością wielodyscyplinarnego leczenia.

U chorych niekwalifikujących się do równoczesnej radiochemioterapii z powodu gorszego stanu ogólnego, współistniejących chorób lub dużej masy guza można zastosować indukcyjną chemioterapię (2-3 cykle; schematy zawierające pochodne platyny $\mathrm{w}$ skojarzeniu $\mathrm{z}$ winorelbiną, gemcytabiną lub taksoidami). W tym wypadku szczególnie ważne jest zachowanie możliwe krótkiej przerwy (2-3 tygodnie) pomiędzy zakończeniem chemioterapii i rozpoczęciem radioterapii. Bezpośrednio przed rozpoczęciem radioterapii konieczna jest ponowna ocena zasięgu nowotworu.

Nie ma wskazań do kojarzenia równoczesnej radiochemioterapii z chemioterapią indukcyjną lub konsolidującą oraz z lekami ukierunkowanymi molekularnie.

\section{Chemioterapia I linii w zaawansowanym NDRP}

Zastosowanie paliatywnej chemioterapii z udziałem cisplatyny u chorych na zaawanso- wanego NDRP wydłuża medianę całkowitego przeżycia średnio o około 1,5 miesiąca i zwiększa prawdopodobieństwo jednorocznego przeżycia o około $9 \%$ w porównaniu z najlepszym leczeniem objawowym [73]. Odsetek jednorocznych i dwuletnich wskaźników przeżycia pod wpływem chemioterapii wynosi w tej grupie odpowiednio $20-40 \%$ i 5-10\% [74]. Niezależnie od tego u części chorych uzyskuje się zmniejszenie dolegliwości związanych z nowotworem. Obecnie standardem są dwulekowe schematy z udziałem leków trzeciej generacji w połączeniu z pochodnymi platyny [75, 76]. Trzylekowe schematy nie są skuteczniejsze od dwulekowych [77-80]. Schematy zawierające cisplatynę są nieco skuteczniejsze od ich odpowiedników zawierających karboplatynę, zwłaszcza w skojarzeniu z lekami III generacji [81]. Stosowane obecnie dwulekowe schematy oparte na pochodnych platyny nie różnią się istotnie skutecznością [82-85], przy czym u chorych na raki niepłaskonabłonkowe (rak gruczołowy i rak wielkokomórkowy) skojarzenie cisplatyny z pemetreksedem jest nieco skuteczniejsze od skojarzenia z innymi lekami, podczas gdy u chorych na raka płaskonabłonkowego schemat zawierający pemetreksed związany jest z nieco krótszym czasem przeżycia [86, 87]. Pemetreksed jest w Polsce zarejestrowany wyłącznie w skojarzeniu z cisplatyną.

U większości chorych dla osiągnięcia korzyści klinicznej wystarczające jest podanie 3-4 cykli chemioterapii [88-91]. Jej kontynuowanie wydłuża czas wolny od progresji, ale nie wpływa na czas całkowitego przeżycia i zwiększa toksyczność leczenia [92].

Nową koncepcją terapeutyczną jest tzw. leczenie podtrzymujące, polegające na zastosowaniu pojedynczego leku cytotoksycznego po zakończeniu standardowej chemioterapii [93-95]. Podtrzymujące leczenie pemetreksedem pozwala uzyskać wydłużenie czasu przeżycia wolnego od progresji i czasu całkowitego przeżycia [94, 95], przy czym analiza podgrup wykazała, że korzyść dotyczyła wyłącznie chorych na raka niepłaskonabłonkowego. Dotychczasowe badania oceniające skuteczność podtrzymującego leczenia mają pewne ograniczenia, np. w większości z nich tylko niewielka część chorych w grupach kontrolnych otrzymywała w momencie progresji nowotworu „odroczoną” podtrzymującą chemioterapię. Brakuje także wiarygodnych klinicznych czynników predykcyjnych dla korzyści z podtrzymującego leczenia, danych na temat jego wpływu na jakość życia oraz formalnych analiz farmakoekonomicznych. Obecnie jedynym zarejestrowa- 
nym lekiem cytotoksycznym w podtrzymującym leczeniu NDRP jest pemetreksed, jednak nie jest on w Polsce objęty programem lekowym.

Wiek chorego nie jest niezależnym czynnikiem rokowniczym, ale u starszych osób często problemem są współistniejące inne poważne choroby. Wyniki badań z randomizacją oraz ich metaanalizy wskazują, że u chorych w wieku powyżej 70. roku życia dwulekowe schematy chemioterapii pozwalają uzyskać nieco lepsze wyniki niż jednolekowa chemioterapia, ale równocześnie są bardziej toksyczne [96-98]. W tej grupie wiekowej dobry paliatywny efekt można także uzyskać pod wpływem jednolekowej chemoterapii [99]. Leczenie chorych w 2. stopniu sprawności według skali WHO jest przedmiotem kontrowersji, aczkolwiek niektóre badania wskazują na możliwość uzyskania w tej grupie korzyści pod wpływem jedno- lub dwulekowej chemioterapii [100-102].

\section{Zalecenia}

Chemioterapia I linii w zaawansowanym NDRP powinna być stosowana u chorych spełniających następujące kryteria:

- rozsiany (stopień IV) lub miejscowo zaawansowany (stopień IIIB) nowotwór; w drugim przypadku wyłącznie u chorych, którzy nie kwalifikują się do radykalnej radioterapii lub radiochemioterapii;

- stopień sprawności 0 lub 1 według klasyfikacji WHO oraz wybrani chorzy w stopniu 2;

- możliwość przeprowadzenia obiektywnej oceny odpowiedzi na leczenie (preferowana jest ocena mierzalnych zmian);

- brak istotnego ubytku masy ciała;

- brak współwystępujących chorób uniemożliwiających przeprowadzenie planowanego leczenia.

Zaleca się stosowanie dwulekowych schematów z udziałem cisplatyny w połączeniu z lekiem III generacji: winorelbiną, gemcytabiną, paklitakselem, docetakselem lub pemetreksedem (ostatni $\mathrm{z}$ wymienionych wyłącznie $\mathrm{u}$ chorych na raka niepłaskonabłonkowego). Zalecenia te dotyczą także chorych z progresją nowotworu po wcześniejszej chemioterapii stosowanej w skojarzeniu z chirurgią lub radioterapią o radykalnej intencji. Stosowanie pemetreksedu wymaga suplementacji witaminą B12 i kwasem foliowym. Nie powinno się przekraczać 4 cykli chemioterapii; dodatkowe 2 cykle można rozważyć jedynie u chorych z dobrą tolerancją leczenia i postępującą odpowiedzią w kolejnych badaniach obrazowych. U chorych w wieku powyżej 70. roku życia, którzy są w stanie sprawności 0-1 w skali WHO, można zastosować standardową dwulekową chemioterapię ( $w$ tym schematy bez udziału pochodnych platyny). U wybranych chorych w podeszłym wieku lub w 2. stopniu sprawności, którzy nie kwalifikują się do dwulekowych schematów, można rozważyć zastosowanie jednolekowej chemioterapii (np. winorelbina lub gemcytabina). W trakcie chemioterapii konieczne jest wykonywanie co 2 cykle badań oceniających obiektywną odpowiedź.

Podtrzymujące leczenie pemetreksedem jako kontynuacje paliatywnej chemioterapii I linii można rozważać jedynie u wybranych chorych z rozpoznaniem raka gruczołowego lub wielkokomórkowego, z obiektywną odpowiedzią lub stabilizacją choroby, w dobrym stanie ogólnym i bez przetrwałych niepożądanych działań wcześniejszej chemioterapii.

Chemioterapię można kojarzyć z innymi formami paliatywnego leczenia poprawiającymi jakość życia (paliatywną radioterapią, metodami wewnątrzoskrzelowymi itp.). W trakcie chemioterapii nie należy stosować inhibitorów EGFR.

\section{Chemioterapia II linii}

Niemal u wszystkich chorych na zaawansowanego NDRP otrzymujących chemioterapię I linii dochodzi do progresji nowotworu. Celowość stosowania w tej grupie chemioterapii II linii pozostawała przez długi czas przedmiotem kontrowersji.

Zbiorcze wyniki badań przeprowadzonych w latach 1996-2005 wskazują na lepsze wskaźniki przeżycia chorych otrzymujących chemioterapię II linii w porównaniu z leczeniem wyłącznie objawowym [103]. Odpowiedź na chemioterapię II linii jest jednak krótka, i u większości chorych w ciągu kilku miesięcy dochodzi do ponownej progresji choroby. W leczeniu II linii stosuje się najczęściej pojedyncze leki, bowiem ich skuteczność mierzona czasem do progresji i czasem całkowitego przeżycia, jest podobna do uzyskiwanej przy użyciu wielolekowej chemioterapii [103, 104].

Udowodnioną aktywność w leczeniu chorych po wcześniejszej chemioterapii z udziałem pochodnych platyny wykazują docetaksel [106, 107] i pemetreksed [108], przy czym toksyczność hematologiczna pemetreksedu jest mniejsza. U chorych na raka niepłaskonabłonkowego nieco skuteczniejszy jest pemetreksed, a u chorych na raka płaskonabłonkowego — docetaksel [109, 110].

Korzyść kliniczna związana z chemioterapią II linii dotyczy głównie chorych z odpowiedzią na pierwszorazowe leczenie, $w$ dobrym stanie 
sprawności, z mniejszą masą nowotworu i dłuższym niż 3 miesiące czasem bez progresji po chemioterapii I linii.

\section{Zalecenia}

Chemioterapię II linii można rozważyć u chorych na zaawansowanego NDRP, którzy pod wpływem pierwszorazowego leczenia uzyskali obiektywną odpowiedź trwającą przynajmniej 3 miesiące. Ze względu na swój paliatywny charakter chemioterapia II linii jest uzasadniona wyłącznie u chorych w dobrym stanie ogólnym i bez utrwalonych niepożądanych następstw wcześniejszego leczenia. W leczeniu II linii można zastosować docetaksel lub pemetreksed; stosowanie innych leków cytotoksycznych nie ma uzasadnienia. W doborze chemioterapii należy uwzględnić typ histologiczny NDRP (pemetreksed - wyłącznie rak niepłaskonabłonkowy, docetaksel - każdy typ NDRP). Stosowanie pemetreksedu wymaga suplementacji witaminą B12 i kwasem foliowym. Nie zaleca się stosowania chemioterapii III linii.

\section{Leki molekularnie ukierunkowane (tzw. „celowane") w zaawansowanym NDRP}

\section{Inhibitory EGFR oraz inhibitory receptorów $\mathrm{z}$ rodziny HER}

Pobudzenie EGFR i innych białek szlaku EGFR nasila proliferację oraz hamuje apoptozę komórek nowotworowych, co zwiększa zdolność nowotworu do naciekania i tworzenia przerzutów. Zahamowanie szlaku EGFR można osiągnąć przy użyciu niskocząsteczkowych odwracalnych inhibitorów kinazy tyrozynowej EGFR (erlotynib i gefitynib), nieodwracalnych inhibitorów receptorów z rodziny HER (afatynib) lub monoklonalnych przeciwciał wiążących się z zewnątrzkomórkową domeną EGFR (cetuksymab).

Wrażliwość na inhibitory EGFR jest silnie związana z obecnością aktywujących mutacji w eksonach 18.-21. genu EGFR, najczęściej delecji w eksonie 19. lub mutacji punktowej L858R w eksonie 21. Występujące w eksonie 20. mutacje punktowe i insercje są na ogół związane z opornością na inhibitory EGFR. Aktywność inhibitorów EGFR w rakach z rzadkimi aktywującymi mutacjami genu EGFR występującymi w eksonach 18-21 jest nadal przedmiotem badań. Mutacje aktywujące $E G F R$ występują w rakach gruczołowych u około $10-15 \%$ chorych rasy białej i u $30-60 \%$ chorych populacji wschodnioazjatyckiej (częściej u kobiet, osób niepalących i chorych na raka gruczołowego) [111, 112]. Wyniki niektórych badań klinicznych wskazują, że delecje w eksonie 19. mogą być związane z wyższą wrażliwością na inhibitory EGFR niż substytucja L858R [113].

Badania z losowym doborem chorych wykazały, że stosowane w sposób ciągły inhibitory EGFR równocześnie z chemioterapią 1. linii zawierającą pochodne platyny nie zwiększa jej skuteczności [114-117]. W ostatnich latach przeprowadzono kilka dużych badań III fazy, w których w leczeniu I linii porównywano skuteczność gefitynibu, erlotynibu lub afatynibu ze standardowymi schematami chemioterapii opartymi na pochodnych platyny [113, 118-120]. Badania te wykazały, że wśród ogółu chorych skuteczność obu metod jest podobna. W podgrupie chorych z aktywującymi mutacjami genu EGFR wykazano jednak wyraźną wyższość inhibitorów EGFR w zakresie czasu przeżycia do progresji, odsetka odpowiedzi i jakości życia, natomiast u chorych bez mutacji skuteczniejsza była chemioterapia. Czas całkowitego przeżycia był w porównywanych grupach podobny, co najpewniej wynikało z efektu crossover, czyli stosowania inhibitorów EGFR w kolejnej linii leczenia u chorych z mutacjami genu EGFR, u których doszło do progresji po chemioterapii I linii.

Rolę inhibitorów EGFR w II i dalszych liniach leczenia zaawansowanego NDRP oceniono w kilku dużych badaniach III fazy. W badaniu BR.21, obejmującym chorych po jednej lub dwóch liniach wcześniejszej chemioterapii i niekwalifikujących się do dalszej chemioterapii, erlotynib okazał się skuteczniejszy niż placebo w zakresie czasu przeżycia i jakości życia [121], przy czym korzyść ta była największa u chorych ze zwiększoną liczbą kopii genu EGFR [122]. W podobnie zaplanowanym badaniu ISEL, porównującym gefitynib i placebo, nie wykazano znamiennego wydłużenia czasu przeżycia w grupie otrzymującej gefitynib, z wyjątkiem podgrupy chorych niepalących i pochodzących ze wschodniej Azji [123]. $\mathrm{W}$ badaniu INTEREST, porównującym gefitynib $\mathrm{z}$ docetakselem u chorych poddanych wcześniej chemioterapii, oraz w badaniu TITAN, porównującym erlotynib z docetakselem lub pemetreksedem, skuteczność badanych metod leczenia była podobna w całej badanej populacji, przy czym chorzy z mutacjami genu EGFR odnieśli większą korzyść $\mathrm{z}$ terapii inhibitorami EGFR [124-126].

We wszystkich badaniach najczęściej obserwowanymi niepożądanymi objawami związanymi z leczeniem inhibitorami EGFR były zmiany skórne (najczęściej wysypka) oraz biegunka. Rzadziej występowały: upośledzenie czynności wątroby, zapalenie błon śluzowych oraz śródmiąższowe zapalenie płuc. 
W ostatnich latach przedmiotem badań była również rola inhibitorów EGFR w podtrzymującym leczeniu stosowanym po zakończeniu chemioterapii. $\mathrm{W}$ badaniu SATURN podtrzymujące leczenie erlotynibem wydłużyło w porównaniu z placebo medianę czasu przeżycia o $10 \mathrm{dni}$ i całkowity czas przeżycia o około 1 miesiąc [127]. Korzyść ta jednak była znacznie większa $\mathrm{w}$ podgrupie chorych z aktywującymi mutacjami genu EGFR. W badaniu INFORM, w którym w leczeniu podtrzymującym stosowano gefitynib, nie stwierdzono znamiennych różnic w odniesieniu do czasu całkowitego przeżycia, natomiast czas do progresji był dłuższy w grupie otrzymującej gefitynib [128]. W badaniu ATLAS podtrzymujące leczenie zawierające bewacyzumab z erlotynibem związane było z dłuższym czasem do progresji w porównaniu z leczeniem zawierającym bewacyzumab i placebo [129].

Wskaźniki farmakoekonomiczne dla leczenia erlotynibem i gefitynibem w odniesieniu do ogółu chorych na raka gruczołowego płuca są niekorzystne, co tym bardziej wskazuje na konieczność kwalifikacji do stosowania tych leków na podstawie badań genetycznych. Obowiązujący od lipca 2012 roku program lekowy finansowany przez Narodowy Fundusz Zdrowia zastrzega, iż leczenie I linii inhibitorami EGFR można stosować $\mathrm{u}$ chorych na miejscowo zaawansowanego lub rozsianego gruczolakoraka płuca lub na nowotwór z przewagą tego typu histologicznego, pod warunkiem potwierdzenia obecności mutacji genu EGFR $\mathrm{w}$ eksonie 19. lub 21. (gefitynib) lub potwierdzenia jakiejkolwiek mutacji aktywującej genu EGFR (erlotynib). Oznacza to, iż erlotynib może być stosowany także u chorych z rzadkimi mutacjami aktywującymi w eksonach 18.-21. genu EGFR. Zgodnie z zapisami programu lekowego NFZ w II linii leczenia dopuszczony jest obecnie erlotynib, pod warunkiem spełnienia powyższego kryterium. Gefitynib uzyskał pozytywną opinię Agencji Oceny Technologii Medycznych do stosowania w leczeniu II linii chorych z mutacjami w genie EGFR, ale nie został dotychczas objęty refundacją w ramach programu lekowego.

Zapisy rejestracyjne dotyczące inhibitorów EGFR nie regulują szczegółowo sposobu i metod oznaczania mutacji aktywujących genu EGFR. Zaburzenia te można oznaczać w wycinkach pobranych z pierwotnych guzów płuca (materiał operacyjny, wewnątrzoskrzelowa lub gruboigłowa biopsja), odległych przerzutów oraz zajętych przerzutami węzłów chłonnych. Mutacje te można także oceniać w materiale cytologicznym (np. z EBUS-TBNA, BAC). Materiał tkankowy przecho- wywany jest zwykle w bloczkach parafinowych, a materiał cytologiczny - w bloczkach zawierających komórki nowotworowe (,cytoblokach”) lub w postaci rozmazów na szkiełkach mikroskopowych. Korzystniejsze warunki badania zapewnia duży materiał tkankowy oraz cytoblok. Wstępna ocena materiału musi być przeprowadzona przez patologa, który powinien wybrać fragment guza do badania genetycznego i określić procentową zawartość komórek nowotworowych. W badaniu materiałów zawierających mniej niż 50\% komórek nowotworowych nie zaleca się stosowania metody bezpośredniego sekwencjonowania. Metody diagnostyczne wykorzystujące technikę łańcuchowej reakcji polimerazy w czasie rzeczywistym (real-time PCR) zapewniają wiarygodną analizę materiałów zawierających niski (w granicach 10-50\%) odsetek komórek nowotworowych. Metoda ta jest obecnie preferowana do badania mutacji w genie EGFR. W kwalifikacji chorych na NDRP do leczenia inhibitorami EGFR nie stosuje się oceny liczby kopii genu EGFR, ekspresji białka EGFR (metoda immunohistochemiczna; IHC) oraz mutacji genu KRAS.

Cetuksymab jest monoklonalnym przeciwciałem, które wiąże się z zewnątrzkomórkową domeną EGFR. Lek działa poprzez blokowanie homodimeryzacji i heterodimeryzacji tego receptora, prowadząc do jego internalizacji, degradacji i zahamowania szlaku sygnałowego EGFR. Dodanie cetuksymabu do chemioterapii u chorych na zaawansowanego NDRP z ekspresją białka EGFR pozwoliło uzyskać nieznaczne (5 tygodni) wydłużenie mediany czasu całkowitego przeżycia, przy podobnym czasie przeżycia wolnego od progresji [130]. W innym badaniu III fazy dodanie cetuksymabu do chemioterapii nie miało wpływu na wyniki leczenia [131]. Cetuksymab nie jest obecnie zarejestrowany w Unii Europejskiej u chorych na zaawansowanego NDRP.

\section{Zalecenia}

Nie ma wskazań do równoczesnego stosowania inhibitorów EGFR i chemioterapii I linii u chorych na zaawansowanego NDRP. U chorych z mutacją genu EGFR zastosowanie inhibitorów EGFR w I linii leczenia jest postępowaniem z wyboru. U chorych z mutacją genu EGFR, którzy w I linii otrzymali chemioterapię, zastosowanie inhibitorów EGFR należy rozważyć w II linii. Inhibitorów EGFR nie należy stosować u chorych bez mutacji genu EGFR w komórkach nowotworu. Leczenie podtrzymujące $\mathrm{z}$ udziałem inhibitorów EGFR wymaga dalszych badań. Związana ze stosowaniem inhibitorów EGFR wysypka o słabym 
nasileniu nie wymaga leczenia; w przypadku współistniejącego zakażenia skuteczne są doustne antybiotyki (np. doksycyklina). Rutynowe stosowanie cetuksymabu w zaawansowanym NDRP jest nieuzasadnione.

\section{Inhibitory ALK}

Rearanżacja genu $A L K$ występuje u 3-7\% chorych na NDRP, głównie w raku gruczołowym, nieco częściej u osób niepalących. Zaburzenie to skutkuje powstaniem fuzyjnego genu EML4-ALK i prowadzi do stałego pobudzenia ALK i wewnątrzkomórkowych szlaków przewodzenia sygnału.

Kryzotynib jest inhibitorem receptorów ALK, c-MET i ROS1. Jego skuteczność u chorych na raka gruczołowego z rearanżacją genu $A L K$ potwierdzono $\mathrm{w}$ jednoramiennych badaniach I i II fazy (PROFILE 1001 i 1005) [132, 133] oraz (w porównaniu $\mathrm{z}$ chemioterapią) $\mathrm{w}$ badaniu III fazy (PROFILE 1007) [134]. W badaniach PROFILE 1001 i 1005, obejmujących chorych z progresją po przynajmniej jednej linii chemioterapii, odsetek obiektywnych odpowiedzi wynosił około $60 \%$, a mediana czasu do progresji około 8-9 miesięcy. W badaniu PROFILE 1007, obejmującym chorych z progresją po I linii chemioterapii, leczenie kryzotynibem pozwoliło uzyskać wyższy odsetek odpowiedzi i wydłużenie czasu do progresji w porównaniu z chemioterapią II linii (pemetreksed lub docetaksel). Czas całkowitego przeżycia był w obu grupach podobny, prawdopodobnie z powodu skutecznego leczenia kryzotynibem w kolejnej linii u chorych z grupy kontrolnej (crossover). Kryzotynib wykazuje także wysoką aktywność u chorych z rearanżacją genu ROS1, obecną u 1-2\% chorych na raka gruczołowego [135]. Trwają badania nad inhibitorami ALK drugiej generacji u chorych na NDRP z rearanżacją genu $A L K$ [136].

Do występujących względnie rzadko działań niepożądanych leczenia kryzotynibem należą: hepatotoksyczność, włóknienie i zapalenie płuc, zaburzenia wzroku, leukopenia, zaburzenia jelitowe, bradykardia i wydłużenie odcinka QT w elektrokardiogramie.

Kryzotynib został zarejestrowany w USA u chorych na NDRP z rearanżacją genu $A L K$, potwierdzoną badaniem FISH. Rejestracja na terenie Unii Europejskiej dotyczy chorych z aktywacją ALK (bez określenia metody oznaczania rearanżacji genu $A L K$ ), u których doszło do niepowodzenia uprzedniego leczenia systemowego.

\section{Zalecenia}

Kryzotynib wykazuje znaczną aktywność $\mathrm{u}$ chorych na zaawansowanego NDRP z rearan- żacją genu $A L K$ lub mutacją genu ROS1, u których doszło do niepowodzenia po wcześniejszej chemioterapii. W Polsce kryzotynib nie jest dotychczas dostępny w ramach programów lekowych NFZ. W najbliższej przyszłości można się spodziewać rejestracji innych inhibitorów ALK.

\section{Inhibitory angiogenezy}

Angiogeneza ma istotne znaczenie $\mathrm{w}$ patogenezie wzrostu i rozsiewu nowotworów. Proces ten można hamować, stosując monoklonalne przeciwciała oraz niskocząsteczkowe inhibitory kinaz tyrozynowych VEGFR, PDGFR i FGFR. Rolę bewacyzumabu, przeciwciała anty-VEGF ( $\mathrm{vascu}$ lar endothelial growth factor) w skojarzeniu $\mathrm{z}$ chemioterapią oceniono w trzech badaniach III fazy [137-139]. Do badań tych kwalifikowano chorych z rozpoznaniem niepłaskonabłonkowego zaawansowanego NDRP, w dobrym stanie ogólnym, bez przerzutów do mózgu, krwioplucia, współwystępowania zaburzeń krzepnięcia, konieczności przyjmowania leków przeciwkrzepliwych oraz niekontrolowanego nadciśnienia. W jedynym badaniu dodanie bewacyzumabu do chemioterapii zwiększyło wskaźniki odpowiedzi, przeżycia wolnego od progresji i całkowitego przeżycia [137], natomiast $w$ dwóch pozostałych $[138,139]$ nie uzyskano wydłużenia czasu przeżycia całkowitego. W innym badaniu III fazy wykazano podobną skuteczność schematu z udziałem karboplatyny, pemetreksedu i bewacyzumabu (z podtrzymującym leczeniem pemetreksedem i bewacyzumabem) w porównaniu ze schematem zawierającym karboplatynę, paklitaksel i bewacyzumab (z podtrzymującym leczeniem bewacyzumabem) [140]. Z kolei w badaniu AVAPERL nie wykazano wyższości podtrzymującego leczenia z udziałem bewacyzumabu i pemetreksedu nad podtrzymującym leczeniem z udziałem wyłącznie bewacyzumabu u chorych na NDRP bez progresji po zastosowaniu chemioterapii z udziałem cisplatyny, pemetreksedu i bewacyzumabu [141].

Leczenie bewacyzumabem w połączeniu z chemioterapią opartą o związki platyny jest związane z licznymi działaniami niepożądanymi, w tym ze zwiększonym ryzykiem neutropenii, proteinurii, krwawień, perforacji przewodu pokarmowego oraz powikłań zakrzepowo-zatorowych. Ponadto wielolekowa i długotrwała terapia jest uciążliwa dla chorych [142-144].

Antyangiogenne przeciwciała monoklonalne oraz drobnocząsteczkowe inhibitory kinaz tyrozynowych, w tym hamujące m.in. receptory związane z neoangiogenezą (sorafenib, sunitynib, cedyranib, motezanib, wandetanib, wadimezan, 
nintedanib), są w trakcie badań klinicznych. Wczesne wyniki jednego z badań wykazały wydłużenie PFS i OS u chorych, którzy w II linii leczenia otrzymali docetaksel w połączeniu z nintedanibem (potrójnym inhibitorem angiokinaz) $\mathrm{w}$ porównaniu $\mathrm{z}$ docetakselem $\mathrm{w}$ połączeniu z placebo [145]. Wyniki większości innych ukończonych dotychczas badań są negatywne.

\section{Zalecenia}

Zastosowanie bewacyzumabu tylko nieznacznie zwiększa skuteczność leczenia zaawansowanego NDRP, a równocześnie przedłuża je (leczenie podtrzymujące) i zwiększa jego toksyczność. Z tego powodu, jak również z powodu braku czynników predykcyjnych dla tego leku, nie ma wskazań do jego rutynowego stosowania. Nie wykazano jak dotąd korzyści z zastosowania drobnocząsteczkowych inhibitorów kinaz tyrozynowych receptorów związanych z angiogenezą nowotworową.

\section{Inne terapie ukierunkowane molekularnie i immunoterapia}

Badania nad skutecznością immunoterapii u chorych na NDRP są w toku. Preparat L-BLP25 (tekemotyd), będący liposomalną szczepionką zawierającą antygen MUC1, stosowany w badaniu III fazy (START) w uzupełnieniu radiochemioterapii $\mathrm{u}$ chorych na NDRP $\mathrm{w}$ III stopniu zaawansowania nie wpłynął znamiennie na wydłużenie czasu całkowitego przeżycia i tylko nieznacznie wydłużył czas do progresji [146]. W podgrupie chorych poddanych jednoczasowej radiochemioterapii pod wpływem tekemotydu uzyskano wydłużenie mediany całkowitego przeżycia o 10 miesięcy w porównaniu z grupą otrzymującą placebo.

\section{Zalecenia}

Skuteczność immunoterapii u chorych na NDRP pozostaje przedmiotem badań klinicznych. W najbliższych latach można oczekiwać pojawienia się nowych terapii ukierunkowanych molekularnie, które będą skuteczne w wyselekcjonowanych, często wąskich grupach chorych na NDRP. Konieczne jest przygotowanie laboratoriów genetycznych wiarygodnie określających czynniki predykcyjne kwalifikacji do tej formy leczenia.

\section{Chemioterapia w złośliwym międzybłoniaku opłucnej}

Złośliwy międzybłoniak opłucnej jest u większości chorych rozpoznawany w zaawansowanym stadium, co nie pozwala na podjęcie radykalne- go zabiegu operacyjnego (zewnątrzopłucnowa pleuropneumonektomia lub pleurektomia $\mathrm{z}$ dekortykacją).

Międzybłoniak jest nowotworem o względnie niskiej chemiowrażliwości. Obiektywną odpowiedź uzyskuje się u 20-40\% chorych, a mediana czasu przeżycia wśród ogółu chorych wynosi 6-9 miesięcy. Największą aktywność wykazują leki z grupy antymetabolitów oraz cisplatyna [147]. Wielolekowa chemioterapia w porównaniu z monoterapią zwiększa odsetek odpowiedzi i wydłuża czas przeżycia chorych, ale wartościową metodą poprawiającą jakość życia może być także jednolekowa chemioterapia, np. przy użyciu winorelbiny [148]. W kwalifikacji chorych do chemioterapii, poza typowymi kryteriami (np. stan sprawności lub ubytek masy ciała), należy uwzględnić również typ histologiczny (typ nabłonkowaty lepsze rokowanie, typy mieszany i mięsakowaty - gorsze rokowanie).

W badaniu III fazy wykazano, że dodanie pemetreksedu do cisplatyny zwiększa skuteczność leczenia w odniesieniu do odsetka remisji, czasu do progresji, czasu całkowitego przeżycia oraz wskaźników jakości życia [149]. Prawdopodobieństwo uzyskania korzyści związanej z zastosowaniem pemetreksedu było większe u chorych w dobrym stanie sprawności z typem nabłonkowatym nowotworu, mniejszym zaawansowaniem zmian i prawidłową liczbą białych krwinek [150]. Zastosowanie pemetreksedu w II linii leczenia pozwala uzyskać wydłużenie czasu przeżycia do progresji, ale nie wpływa na czas całkowitego przeżycia [151]. Jeśli pierwszorazowe leczenie pemetreksedem w skojarzeniu z cisplatyną przyniosło obiektywne korzyści, schemat ten można zastosować ponownie [152].

Wyniki dotychczasowych badań II fazy, w których w wybranych grupach chorych kojarzono indukcyjną chemioterapię z miejscowymi metodami, są obiecujące [153-156]. Postępowanie takie można rozważyć u wybranych chorych w I-III stopniu zaawansowania i bez przerzutów w węzłach chłonnych śródpiersia. Nie ma natomiast dowodów wskazujących na skuteczność pooperacyjnej chemioterapii. Nadal eksperymentalny charakter mają inne metody systemowego leczenia (np. leki immunomodulujące czy molekularnie ukierunkowane).

\section{Zalecenia}

Paliatywną chemioterapię zaawansowanego złośliwego międzybłoniaka opłucnej można rozważyć u chorych w dobrym stanie sprawności, ze zmianami umożliwiającymi obiektywną 
ocenę odpowiedzi na leczenie (zalecana jest klasyfikacja RECIST z modyfikacją dla złośliwego międzybłoniaka opłucnej). Najbardziej korzystny paliatywny efekt uzyskuje się pod wpływem schematu zawierającego pemetreksed i cisplatynę. Alternatywą może być monoterapia przy użyciu cisplatyny, jednego z antymetabolitów (analog kwasu foliowego lub pirymidyn) lub doksorubicyny. Skojarzone leczenie z udziałem chirurgii, chemioterapii i radioterapii powinno być prowadzone wyłącznie w wysokospecjalistycznych ośrodkach, dysponujących doświadczonym zespołem onkologów klinicznych i chirurgów klatki piersiowej oraz dostępem do nowoczesnych technik radioterapii.

\section{Podsumowanie}

Zalecenia zawarte w niniejszym dokumencie dotyczą codziennej praktyki klinicznej, a ich celem jest wdrożenie i ujednolicenie standardów wielodyscyplinarnego leczenia NDRP i międzybłoniaka opłucnej z uwzględnieniem krajowych możliwości. Autorzy opracowania pragną równocześnie zwrócić uwagę na znaczenie prospektywnych badań klinicznych w rozwoju wiedzy na temat biologii i kliniki omawianych nowotworów. Badania te umożliwiają również uczestniczącym $\mathrm{w}$ nich chorym dostęp do nowoczesnych technologii i innowacyjnych leków. Ważny jest więc szeroki udział chorych w tych badaniach, szczególnie jeśli wartość leczenia oceniana jest w kontekście biologicznych cech nowotworu.

\section{Konflikt interesów}

Jacek Jassem: Roche - grant naukowy; Boehringer Ingelheim, Eli Lilly — komitet doradczy; Astra Zeneca, Roche - wykład; Wojciech Biernat: Roche, Astra Zeneca, GlaxoSimthKline, Pfizer — udział w badaniach naukowych; Maciej Bryl: Roche, Eli Lilly, Astra Zeneca, Pierre Fabre —wykłady; Boehringer — udział w spotkaniu ekspertów; Joanna Chorostowska-Wynimko: Roche, Boehringer Ingelheim, Astra Zeneca - wykłady; Boehringer Ingelheim, Novartis - komitet doradczy; Rafał Dziadziuszko: Boehringer Ingelheim, Pfizer - komitet doradczy; Boehringer Ingelheim, Pfizer, Eli Lilly, Astra Zeneca - wykład; Paweł Krawczyk: Abbott, Roche, Eli Lilly, Astra Zeneca, Boehringer - wykład; Boehringer Ingelheim, Astra Zeneca, Eli Lilly - komitet doradczy; Radzisław Kordek: Roche - wykonanie opinii Dariusz M. Kowalski: Roche, Astra Zeneca, Eli
Lilly — wykład; Boehringer Ingelheim, Eli Lilly — komitet doradczy; Maciej Krzakowski: Boehringer Ingelheim, Eli Lilly - udział w spotkaniu ekspertów; Włodzimierz Olszewski: Boehringer Ingelheim - komitet doradczy, wykłady; Eli Lilly, Astra Zeneca, Pfizer - wykłady; Tadeusz Orłowski: Eli Lilly - wykład; Rodryg Ramlau: Boehringer Ingelheim, Eli Lilly - komitet doradczy; Boehringer Ingelheim, Eli Lilly, Roche, Astra Zeneca - wykłady; Witold Rzyman: brak konfliktu interesu.

\section{Piśmiennictwo}

1. Wojciechowska U., Didkowska J. Nowotwory złośliwe w Polsce w 2012 ro- ku. Nowotwory J. Oncol. 2013; 63: 197-216.

2. Naruke T., Goya T., Tsuchiya R. i wsp. Prognosis and survival in resected lung carcinoma based on the international staging system. J. Thorac. Cardiovasc. Surg. 1998; 96: 440-447.

3. Jassem J., Skokowski J., Dziadziuszko R. i wsp. Results of surgical treatment of non-small cell lung cancer: validation of the new postoperative pathologic TNM classification. J. Thorac. Cardiovasc. Surg. 2000; 119: 1141-1146.

4. Henschke CI., Yankelevitz DF., Libby DM. i wsp. Survival of patients with stage I lung cancer detected on CT screening. N. Engl. J. Med. 2006; 355: 1763-1771.

5. Jassem J., Drosik K., Dziadziuszko R. i wsp. Zalecenia dotyczące systemowego leczenia niedrobnokomórkowego raka płuca i złośliwego międzybłoniaka opłucnej: Konferencja okrągłego stołu. Nowotwory J. Oncol. 2005; 55: 160-166.

6. Jassem J., Drosik K., Dziadziuszko R. i wsp. Systemowe leczenie niedrobnokomórkowego raka płuca i złośliwego międzybłoniaka opłucnej: uaktualnione zalecenia oparte na wynikach wiarygodnych badań klinicznych. Nowotwory J. Oncol. 2007; 57: 71-78.

7. Jassem J., Biernat W., Drosik K. i wsp. Uaktualnione zalecenia dotyczące systemowego leczenia niedrobnokomórkowego raka płuca i złośliwego międzybłoniaka opłucnej. Nowotwory J. Oncol. 2010; 60: 51-63

8. Thunnissen E., Kerr KM., Herth FJF. i wsp. The challenge of NSCLC diagnosis and predictive analysis on small samples. Practical approach of a working group. Lung Cancer 2012 76: 1-15.

9. Barlesi F., Pinot D., Legoffic A. i wsp. Positive thyroid transcription factor 1 staining strongly correlates with survival of patients with adenocarcinoma of the lung. Br. J. Cancer 2005; 93: 450-452.

10. Camilo R., Capelozzi V.L., Siqueira S.A., Del Carlo Bernardi F. Expression of p63, keratin 5/6, keratin 7, and surfactant-A in non-small cell lung carcinomas. Hum. Pathol. 2006; 37: 542-546.

11. Johansson L. Histopathologic classification of lung cancer: Relevance of cytokeratin and TTF-1 immunophenotyping. Ann. Diagn. Pathol. 2004; 8: 259-267.

12. Kalhor N., Zander DS., Liu J. TTF-1 and p63 for distinguishing pulmonary small-cell carcinoma from poorly differentiated squamous cell carcinoma in previously pap-stained cytologic material. Mod. Pathol. 2006; 19: 1117-1123.

13. Kargi A., Gurel D., Tuna B. The diagnostic value of TTF-1, CK 5/6, and p63 immunostaining in classification of lung carcinomas. Appl. Immunohistochem. Mol. Morphol. 2007; 15: 415-420.

14. Khayyata S., Yun S., Pasha T. i wsp. Value of P63 and CK5/6 in distinguishing squamous cell carcinoma from adenocarcinoma in lung fine-needle aspiration specimens. Diagn. Cytopathol. 2009; 37: 178-183.

15. Sturm N., Lantuejoul S., Laverriere MH. i wsp. Thyroid transcription factor 1 and cytokeratins 1, 5, 10, 14 (34betaE12) expression in basaloid and large-cell neuroendocrine carcinomas of the lung. Hum. Pathol. 2001; 32: 918-925.

16. Tan D., Li Q., Deeb G. i wsp. Thyroid transcription factor-1 expression prevalence and its clinical implications in non-small 
cell lung cancer: a high-throughput tissue microarray and immunohistochemistry study. Hum. Pathol. 2003; 34: 597-604.

17. Nicholson A.G., Gonzalez D., Shah P. i wsp. Refining the diagnosis and EGFR status of non-small cell lung carcinoma in biopsy and cytologic material, using a panel of mucin staining, TTF-1, cytokeratin 5/6, and P63, and EGFR mutation analysis. J. Thorac. Oncol. 2010; 5: 436-441.

18. Van Schil PE., Sihoe AD., Travis WD. Pathologic classification of adenocarcinoma of lung. J. Surg. Oncol. 2013; 108: 320-326.

19. Travis WD., Brambilla E., Noguchi M. i wsp. International Association for the Study of Lung Cancer/American Thoracic Society/European Respiratory Society international multidisciplinary classification of lung adenocarcinoma. J. Thorac. Oncol. 2011; 6: 244-285.

20. Travis W.D., Brambilla E., Muller-Hermelink H.K., Harris C.C. World Health Organization Classification of tumours. Pathology and genetics of tumours of the lung, pleura, thymus and heart. Lyon: IARC; 2004.

21. Yi E.S., Boland J.M., Maleszewski J.J. i wsp. Correlation of IHC and FISH for ALK gene rearrangement in non-small cell lung carcinoma: IHC score algorithm for FISH. J. Thorac. Oncol. 2011; 6: 459-465.

22. Paik J.H., Choe G., Kim H. i wsp. Screening of anaplastic lymphoma kinase rearrangement by immunohistochemistry in non-small cell lung cancer: correlation with fluorescence in situ hybridization. J. Thorac. Oncol. 2011; 6: 466-472.

23. Sholl L.M., Sun H., Butaney M. i wsp. ROS1 immunohistochemistry for detection of ROS1-rearranged lung adenocarcinomas. Am. J. Surg. Pathol. 2013; 37: 1441-1449.

24. Stahel R.A., Weder W., Lievens Y. i wsp. Malignant pleural mesothelioma: ESMO Clinical Practice Guidelines for diagnosis, treatment and follow-up. Ann. Oncol. 2010; 21 (suppl. 5): v126-128.

25. Butnor K.J., Sporn T.A., Ordonez N.G. Recommendations for the reporting of pleural mesothelioma. Virchows. Arch. 2007; 450: $15-23$.

26. Churg A., Colby T.V., Cagle P. i wsp. The separation of benign and malignant mesothelial proliferations. Am. J. Surg. Pathol. 2000; 24: 1183-11200.

27. Rosell R., Gomez-Codina J., Camps C. i wsp. A randomized trial comparing preoperative chemotherapy plus surgery with surgery alone in patients with non-small-cell lung cancer. $\mathrm{N}$. Engl. J. Med. 1994; 330: 153-158.

28. Roth J.A., Fosella F., Komaki R. i wsp. A randomized trial comparing perioperative chemotherapy and surgery with surgery alone in resectable stage IIIA non-small-cell lung cancer. J. Natl. Cancer Inst 1994; 86: 673-680.

29. Depierre A., Milleron B., Moro-Sibilot D. i wsp. Preoperative chemotherapy followed by surgery compared with primary surgery in resectable stage I (except T1N0), II, and IIIa nonsmall-cell lung cancer. J. Clin. Oncol. 2002; 20: 247-253.

30. Gilligan D., Nicolson M., Smith I. i wsp. Preoperative chemotherapy in patients with resectable non-small cell lung cancer: results of the MRC LU22/NVALT 2/EORTC 08012 multicentre randomised trial and update of systematic review. Lancet 2007; 369: 1929-1937.

31. Pisters K., Vallieres E., Crowley JJ. i wsp. Surgery with or without preoperative paclitaxel and carboplatin in early-stage non-small-cell lung cancer: Southwest Oncology Group Trial S9900, an intergroup, randomized, phase III trial. J. Clin. Oncol. 2010; 28:1843-1849.

32. Scagliotti G.V., Pastorino U., Vansteenkiste J.F. i wsp. Randomized phase III study of surgery alone or surgery plus preoperative gemcitabine-cisplatin in stages IB to IIIA of non-small-cell lung cancer. J. Clin. Oncol. 2012; 30: 172-178.

33. Song W.A., Zhou NK., Wang W. i wsp. Survival benefit of neoadjuvant chemotherapy in non-small cell lung cancer: an updated meta-analysis of 13 randomized control trials. J. Thorac. Oncol. 2010; 5: 510-516.

34. Felip E., Rosell R., Maestre J.A. i wsp. Preoperative chemotherapy plus surgery versus surgery plus adjuvant chemotherapy versus surgery alone in early-stage non-small cell lung cancer. J. Clin. Oncol. 2010; 28: 3138-3145.

35. Lim E., Harris G., Patel A. i wsp. Preoperative versus postoperative chemotherapy in patients with resectable non-small cell lung cancer: systematic review and indirect comparison of randomized trials. J. Thorac. Oncol. 2009; 4: 1380-1388.
36. van Meerbeeck J.P., Kramer G.W., Van Schil PE. i wsp. Randomized controlled trial of resection versus radiotherapy after induction chemotherapy in stage IIIA-N2 non-small-cell lung cancer. J. Natl. Cancer Inst. 2007; 99: 442-450.

37. Albain K.S., Swann R.S., Rusch V.W. i wsp. Radiotherapy plus chemotherapy with or without surgical resection for stage III non-small-cell lung cancer: a phase III randomised controlled trial. Lancet 2009; 374: 379-386.

38. Thomas M., Rübe Ch., Hofknecht P. i wsp. Effect of preoperative chemoradiation in addition to preoperative chemotherapy: a randomised trial in stage III non-small cell lung cancer. Lancet. Oncol. 2008; 9: 636-648.

39. Rusch V.W., Giroux D.J., Kraut M.J. i wsp. Induction chemoradiation and surgical resection for superior sulcus non-small cell lung carcinomas: long-term results of Southwest Oncology Group Trial 9416 (Intergroup Trial 0160). J. Clin. Oncol. 2007; 25: 313-318.

40. Kunitoh H., Kato H., Tsuboi M. i wsp. Phase II trial of preoperative chemoradiotherapy followed by surgical resection in patients with superior sulcus non-small cell lung cancers: report of Japan Clinical Oncology Group trial 9806. J. Clin. Oncol. 2008; 26: 644-649.

41. Kappers I., van Sandick J.W., Burgers J.A. i wsp. Results of combined modality treatment in patients with non-small-cell lung cancer of the superior sulcus and the rationale for surgical resection. Eur. J. Cardiothorac. Surg. 2009; 36: 741-746.

42. Keller S.M., Adak S., Wagner H. i wsp. A randomized trial of postoperative adjuvant therapy in patients with completely resected stage II or IIIA non-small cell lung cancer. N. Engl. J. Med. 2000; 343: 1217-1222.

43. Waller D., Peake M.D., Stephens R.J. i wsp. Chemotherapy for patients with non-small cell lung cancer: the surgical setting of the Big Lung Trial. Eur. J. Cardiothorac. Surg. 2004; 26: 173-182.

44. Scagliotti G.V., Fossati R., Torri V. i wsp. Randomized study of adjuvant chemotherapy for completely resected stage I, II or IIIA non-small cell lung cancer. J. Natl. Cancer. Inst 2003; 95: 1453-1461.

45. The International Adjuvant Lung Cancer Trial Collaborative Group. Cisplatin-based adjuvant chemotherapy in patients with completely resected non-small cell lung cancer. N. Engl. J. Med. 2004; 350: 351-360.

46. Winton T., Livingston R., Johnson D. i wsp. Vinorelbine plus cisplatin vs. observation in resected non-small-cell lung cancer. N. Engl. J. Med. 2005; 352: 2589-2597.

47. Strauss GM., Herndon J.E. 2nd., Maddaus MA. i wsp. Adjuvant paclitaxel plus carboplatin compared with observation in stage IB non-small-cell lung cancer: CALGB 9633 with the Cancer and Leukemia Group B, Radiation Therapy Oncology Group, and North Central Cancer Treatment Group Study Groups. J. Clin. Oncol. 2008; 26: 5043-5051.

48. Kato H., Ichinose Y., Ohta M. i wsp. A randomized trial of adjuvant chemotherapy with uracil-tegafur for adenocarcinoma of the lung. N. Engl. J. Med. 2004; 350: 1713-1721.

49. Douillard J-Y., Rosell R., De Lena M. i wsp. Adjuvant vinorelbine plus cisplatin versus observation in patients with completely resected stage IB-IIIA non-small-cell lung cancer (Adjuvant Navelbine International Trialist Association [ANITA]): a randomised controlled trial. Lancet Oncol.. 2006; 7: 719-727.

50. Butts C.A., Ding K., Seymour L. i wsp. Randomized phase III trial of vinorelbine plus cisplatin compared with observation in completely resected stage IB and II non-small cell lung cancer: updated survival analysis of JBR-10. J. Clin. Oncol 2010; 28: 29-34.

51. Arriagada R., Dunant A., Pignon J-P. i wsp. Long-term results of the International Adjuvant Lung Cancer Trial evaluating adjuvant cisplatin-based chemotherapy in resected lung cancer. J. Clin. Oncol. 2010; 28: 35-42.

52. Pignon JP., Tribodet H., Scagliotti GV. i wsp. Lung Adjuvant Cisplatin Evaluation (LACE): a pooled analysis by the LACE Collaborative Group. J. Clin. Oncol. 2008; 26: 3552-3559.

53. Arriagada R., Auperin A., Burdett S. i wsp. NSCLC Metaanalyses Collaborative Group. Adjuvant chemotherapy, with or without postoperative radiotherapy, in operable non-smallcell lung cancer: two meta-analyses of individual patient data. Lancet 2010; 375: 1267-1277. 
54. Jassem J. Combined chemotherapy and radiation in locally advanced non-small-cell lung cancer. Lancet Oncol. 2001; 2: 335-342.

55. Le Chevalier T., Arriagada R., Quoix E. i wsp. Radiotherapy alone versus combined chemotherapy and radiotherapy in nonresectable non-small-cell lung cancer: first analysis of a randomized trial in 353 patients. J. Natl. Cancer Inst. 1991; 83: $417-423$.

56. Dillman R.O., Seagren S.L., Propert K.J. i wsp. A randomized trial of induction chemotherapy plus high-dose radiation versus radiation alone in stage III non-small-cell lung cancer. $\mathrm{N}$. Engl. J. Med. 1990; 323: 940-945.

57. Schaake-Koning C., van den Bogaert W., Delasio O i wsp. Effects of concomitant cisplatin and radiotherapy on inoperable non-small-cell lung cancer. N. Engl. J. Med. 1992; 326: 524-530.

58. Sause W., Kolesar P., Taylor S. i wsp. Final results of phase III trial in regionally advanced unresectable non-small cell lung cancer: Radiation Therapy Oncology Group, Eastern Cooperative Oncology Group, and Southwest Oncology Group. Chest 2000; 117: 358-364.

59. Marino P., Preatoni A., Cantoni A. Randomized trials of radiotherapy alone versus combined chemotherapy and radiotherapy in stages IIIa and IIIb nonsmall cell lung cancer. A meta-analysis. Cancer 1995; 76: 593-601.

60. Pritchard R.S., Anthony S.P. Chemotherapy plus radiotherapy compared with radiotherapy alone in the treatment of locally advanced, unresectable, non-small-cell lung cancer. A metaanalysis. Ann Intern Med 1996; 125: 723-729.

61. Fournel P., Robinet G., Thomas P. i wsp. Randomized phase III trial of sequential chemoradiotherapy compared with concurrent chemoradiotherapy in locally advanced non-small-cell lung cancer: Groupe Lyon-Saint-Etienne d'Oncologie Thoracique-Groupe Français de Pneumo-Cancérologie NPC 95-01 Study. J. Clin. Oncol. 2005; 23: 5910-5917.

62. Furuse K., Fukuoka M., Kawahara M. i wsp. Phase III study of concurrent versus sequential thoracic radiotherapy in combination with mitomycin, vindesine, and cisplatin in unresectable stage III non-small-cell lung cancer. J. Clin. Oncol. 1999; 17: 2692-2699.

63. Curran W.J. Jr., Paulus R., Langer C.J. i wsp. Sequential vs. concurrent chemoradiation for stage III non-small cell lung cancer: randomized phase III trial RTOG 9410. J. Natl. Cancer Inst. $2011 ; 103$ : 1452-1460.

64. O’Rourke N., Roqué I Figuls M., Farré Bernadó N., Macbeth F. Concurrent chemoradiotherapy in non-small cell lung cancer. Cochrane Database Syst. Rev. 2010; CD002140.

65. Aupérin A., Le Péchoux C., Rolland E. i wsp. Meta-analysis of concomitant versus sequential radiochemotherapy in locally advanced non-small-cell lung cancer. J. Clin. Oncol. 2010; 28: 2181-2190.

66. De Ruysscher D., Botterweck A., Dirx M. i wsp. Eligibility for concurrent chemotherapy and radiotherapy of locally advanced lung cancer patients: a prospective, population-based study. Ann Oncol 2009; 20: 98-102.

67. Bradley J.D., Paulus R., Komaki R. i wsp. A randomized phase III comparison of standard-dose (60 Gy) versus high-dose (74 Gy) conformal chemoradiotherapy \pm cetuximab for stage III non-small cell lung cancer: Results on radiation dose in RTOG 0617. J. Clin. Oncol. 2013; 15 (suppl): 458s

68. Machtay M., Hsu C., Komaki R. i wsp. Effect of overall treatment time on outcomes after concurrent chemoradiation for locally advanced non-small-cell lung carcinoma: analysis of the Radiation Therapy Oncology Group (RTOG) experience. Int. J. Radiat. Oncol. Biol. Phys. 2005; 63: 667-671.

69. Vokes E.E., Herndon J.E., Kelley M.J. i wsp. Induction chemotherapy followed by chemoradiotherapy compared with chemoradiotherapy alone for regionally advanced unresectable stage III non-small-cell lung cancer: Cancer and Leukemia Group B. J. Clin. Oncol. 2007; 25: 1698-1704.

70. Hanna N.H., Neubauer M., Yiannoutso C. i wsp. Phase III study of cisplatin, etoposide, and concurrent chest radiation with or without consolidation docetaxel in patients with inoperable stage III non-small-cell lung cancer: the Hoosier Oncology Group and U.S. Oncology. J. Clin. Oncol. 2008; 26: 5755-5760.
71. Kelly K., Chansky K., Gaspar L. i wsp. Phase III trial of maintenance gefitinib or placebo after concurrent chemoradiotherapy and docetaxel consolidation in inoperable stage III non -small cell lung cancer: SWOG S0023. J. Clin. Oncol. 2008; 26: 2450-2456.

72. Bradley J., Masters GA., Hu C. i wsp. An intergroup randomized phase III comparison of standard-dose (60 Gy) versus high -dose (74 Gy) chemoradiotherapy (CRT) +/- cetuximab (cetux) for stage III non-small cell lung cancer (NSCLC): Results on cetux from RTOG 0617. IASLC 15th World Conference on Lung Cancer, Sydney 2013, abstr. PL03.05.

73. NSCLC Meta-Analyses Collaborative Group Chemotherapy in addition to supportive care improves survival in advanced non-small-cell lung cancer: A systematic review and meta-analysis of individual patient data from 16 randomized controlled trials. J. Clin. Oncol. 2008; 26: 4617-4625.

74. Socinski M.A., Cromwell R., Hensing T.E. Treatment of non -small-cell lung cancer, stage IV. Chest 2007; 132 (supl): 277289.

75. Baggstrom M.Q., Stinchcombe T.E., Fried D.B. i wsp. Thirdgeneration chemotherapy agents in the treatment of advanced non-small cell lung cancer: a meta-analysis. J. Thorac. Oncol. 2007; 2: 845-853.

76. Goffin J., Lacchetti Ch., Ellis P.M. i wsp. First line systemic chemotherapy in the treatment of advanced non-small cell lung cancer: A systematic review. J. Thorac. Oncol. 2010; 5: 260-274.

77. Delbaldo C., Michelis S., Syz N. i wsp. Benefits of adding a drug to a single-agent or a 2-agent chemotherapy regimen in advanced non-small-cell lung cancer: a meta-analysis. JAMA 2004; 292: 470-484

78. Alberola V., Camps C., Provencio M. i wsp. Cisplatin plus gemcitabine versus a cisplatin-based triplet versus nonplatinum sequential doublets in advanced non-small-cell lung cancer: a Spanish Lung Cancer Group phase III randomized trial. J. Clin. Oncol. 2003; 21: 3207-3213.

79. Hatem A.A., Elttar I., Loberizo Jr F.R. i wsp. Third generation triplet cytotoxic chemotherapy in advanced non-small cell lung cancer: A systematic overview. Lung Cancer 2009; 64: 194-198.

80. Boni C., Tiseo M., Boni L. i wsp. Triplets versus doublets, with or without cisplatin, in the first-line treatment of stage IIIB-IV non-small cell lung cancer (NSCLC) patients: a multicenter randomised factorial trial. Br. J. Cancer 2012; 106: 658-665.

81. Ardizzoni A., Boni L., Tiseo M. i wsp. Cisplatin versus carboplatin-based chemotherapy in first-line treatment of advanced non-small-cell lung cancer: an individual patient data meta-analysis. J. Natl. Cancer Inst. 2007; 99: 847-857.

82. Kelly K., Crowley J., Bunn P.A. Jr. i wsp. Randomized phase III trial of paclitaxel plus carboplatin vs vinorelbine plus cisplatin in the treatment of patients with advanced non-small cell lung cancer: a Southwest Oncology Group Trial. J. Clin. Oncol. 2001; 19: 3210-3218.

83. Schiller J.H., Harrington D., Belani CP. i wsp. Comparison of four chemotherapy regimens for advanced non-small cell lung cancer. N. Engl. J. Med. 2002; 346: 92-98.

84. Greco AF., Gray., JR., Thompson DS. i wsp. Prospective randomized study of four novel chemotherapy regimens in patients with advanced non-small cell lung carcinoma. Cancer 2002; 95: 1279-1285.

85. Gao G., Jiang J., Liang X. i wsp. A meta-analysis of platinum plus gemcitabine or vinorelbine in the treatment of advanced non-small-cell lung cancer. Lung Cancer 2009; 65: 339-344.

86. Scagliotti G.V., Parikh P., von Pawel J. i wsp. Phase III study comparing cisplatin plus gemcitabine with cisplatin plus pemetrexed in chemotherapy-naive patients with advanced-stage non -small-cell lung cancer. J. Clin. Oncol. 2008; 26: 3543-3551.

87. Treat J., Scagliotti GV., Peng G. i wsp. Comparison of pemetrexed plus cisplatin with other first-line doublets in advanced non-small cell lung cancer (NSCLC): A combined analysis of three phase 3 trials. Lung Cancer 2012; 76: 222-227.

88. Park JO., Kim SW., Ahn JS. i wsp. Phase III trial of two versus four additional cycles in patients who are nonprogressive after two cycles of platinum-based chemotherapy in non small-cell lung cancer. J. Clin. Oncol. 2007; 25: 5233-5239. 
89. von Plessen C., Bergman B., Andresen O . i wsp. Palliative chemotherapy beyond three courses conveys no survival or consistent quality-of-life benefits in advanced non-small-cell lung cancer. Br. J. Cancer 2006; 95: 966-573.

90. Socinski M.A., Schell M.J., Peterman A i wsp. A phase III trial comparing a defined duration of therapy vs continuous therapy followed by second line therapy in advanced stage IIIB/IV non-small cell lung cancer. J. Clin. Oncol. 2002; 20: 1335-1343.

91. Smith I.E., O'Brien MER., Talbot D.C. i wsp. Duration of chemotherapy in advanced non-small cell lung cancer: a randomized trial of three vs six courses of mitomycin, vinblastine, and cisplatin. J. Clin. Oncol. 2001; 19: 1336-1343.

92. Soon Y.Y., Stockler M.R., Askie L.M., Boyer M.J. Duration of chemotherapy for advanced non-small-cell lung cancer: a systemic review and meta-analysis of randomized trials. J. Clin. Oncol. 2009; 20: 3277-3284.

93. Brodowicz T., Krzakowski M., Zwitter M. i wsp. Cisplatin and gemcitabine first-line chemotherapy followed by maintenance gemcitabine or best supportive care in advanced non-small cel lung cancer: a phase III trial. Lung Cancer 2006; 52: 155-163.

94. Ciuleanu T., Brodowicz T., Zielinski C. i wsp. Maintenance pemetrexed plus best supportive care versus placebo plus best supportive care for non-small-cell lung cancer: a randomised, double-blind, phase 3 study. Lancet 2009; 374: 1432-1440.

95. Paz-Ares L.G., de Marinis F., Dediu M. i wsp. PARAMOUNT: Final overall survival results of the phase III study of maintenance pemetrexed versus placebo immediately after induction treatment with pemetrexed plus cisplatin for advanced nonsquamous non-small-cell lung cancer. J. Clin. Oncol. 2013; 31: 2895-2904.

96. Guetz G., Uzzan B., Nicolas P. i wsp. Comparison of the efficacy and safety of single-agent and doublet chemotherapy in advanced non-small cell lung cancer in the elderly: a meta-analysis. Crit. Rev. Oncol. Hematol. 2012; 84: 340-349.

97. Quoix E., Zalcman G., Oster JP. i wsp. Carboplatin and weekly paclitaxel doublet chemotherapy compared with monotherapy in elderly patients with advanced non-small-cell lung cancer: IFCT-0501 randomised, phase 3 trial. Lancet 2011; 378: 1079-1088.

98. Frasci G., Lorusso V., Panza N. i wsp. Gemcitabine plus vinorelbine versus vinorelbine alone in elderly patients with advanced non-small cell lung cancer. J. Clin. Oncol. 2000; 18: 2529-2536.

99. Effects of vinorelbine on quality of life and survival of elderly patients with advanced non-small cell lung cancer: the Elderly Lung Cancer Vinorelbine Italian Study Group. J. Natl. Cancer Inst 1999; 91: 66-72.

100. Hainsworth J.D., Spigel D.R., Farley C. i wsp. Weekly docetaxel versus docetaxel/gemcitabine in the treatment of elderly or poor performance status patients with advanced nonsmall cell lung cancer: a randomized phase 3 trial of the Minnie Pearl Cancer Research Network. Cancer 2007; 110: 2027-2034

101. Lilenbaum R.C., Herndon J.E 2nd., List MA. i wsp. Single -agent versus combination chemotherapy in advanced non -small-cell lung cancer: The Cancer and Leukemia Group B (study 9730). J. Clin. Oncol. 2005; 23: 190-196.

102. Zukin M., Barrios C.H., Pereira JR.,. i wsp. Randomized phase III trial of single-agent pemetrexed versus carboplatin and pemetrexed in patients with advanced non-small-cell lung cancer and Eastern Cooperative Oncology Group performance status of 2. J. Clin. Oncol. 2013; 31: 2849-2853.

103. Barlesi F., Jacot W., Astoul P., Pujol J-L. Second-line treatment for advanced non-small-cell lung cancer: a systematic review. Lung Cancer 2006; 51: 159-172.

104. Di Maio M., Chiodini P., Georgoulias V. i wsp. Meta-analysis of single agent chemotherapy compared with combination chemotherapy as a second-line treatment of advanced non -small-cell lung cancer. J. Clin. Oncol. 2009; 27: 1836-1843.

105. Petrelli F., Coinu A., Cabiddu M. i wsp. Platinum rechallenge in patients with advanced NSCLC; A pooled analysis. Lung Cancer 2013; 81: 337-342.

106. Shepherd FA., Dancey J., Ramlau R. i wsp. Prospective randomized trial of docetaxel versus best supportive care in patients with non-small-cell lung cancer previously treated with platinum-based chemotherapy. J. Clin. Oncol. 2000; 18: 2095-2103.

107. Fossella F.V., DeVore R., Kerr R.N. i wsp. Randomized phase III trial of docetaxel versus vinorelbine or ifosfamide in patients with advanced non-small-cell lung cancer previously treated with platinum-containing chemotherapy regimens. The TAX 320 Non-Small Cell Lung Cancer Study Group. J. Clin. Oncol. 2000; 18: 2354-2362.

108. Hanna N., Shepherd FA., Fossella FV. i wsp. Randomized phase III trial of pemetrexed versus docetaxel in patients with non-small-cell lung cancer previously treated with chemotherapy. J. Clin. Oncol. 2004; 22: 1589-1597.

109. Peterson P., Park K., Fossella F. i wsp. Is pemetrexed more effective in adenocarcinoma and large cell lung cancer than in squamous cell carcinoma? A retrospective analysis of a phase III trial of pemetrexed vs docetaxel in previously treated patients with advanced non-small cell lung cancer. J. Thorac. Oncol. 2007; 2: S851 (abstr.)

110. Scagliotti G., Brodowicz T., Shepherd F.A. i wsp. Treatment-by -histology interaction analyses in three phase III trials show superiority of pemetrexed in nonsquamous non-small cell lung cancer. J. Thorac. Oncol. 2011; 6: 64-70.

111. Petrelli F., Borgonovo K., Cabiddu M. i wsp. Efficacy of EGFR tyrosine kinase inhibitors in patients with EGFR-mutated non -small cell lung cancer: a meta-analysis of 13 randomised trials. Clinical Lung Cancer 2012; 13: 107-114.

112. Lee C.K., Brown C., Grala R.J. i wsp. Impact of EGFR inhibitor in non-small cell lung cancer on progression-free and overall survival: a meta-analysis. J. Natl. Cancer Inst 2013; 105: 595-605.

113. Rosell R., Carcereny E., Gervais R. i wsp. Erlotinib versus standard chemotherapy as first-line treatment for European patients with advanced EGFR mutation-positive non-small-cell lung cancer (EURTAC): a multicentre, open-label, randomised phase 3 trial. Lancet Oncol. 2012; 13: 239-246.

114. Herbst RS., Prager D., Hermann R. i wsp. TRIBUTE: a phase III trial of erlotinib hydrochloride (OSI-774) combined with carboplatin and paclitaxel chemotherapy in advanced non -small-cell lung cancer. J. Clin. Oncol. 2005; 23: 5892-5899.

115. Gatzemeier U., Pluzanska A., Szczesna A i wsp. Phase III study of erlotinib in combination with cisplatin and gemcitabine in advanced non-small-cell lung cancer: the Tarceva Lung Cancer Investigation Trial. J. Clin. Oncol. 2007; 25: 1545-1552.

116. Giaccone G., Herbst R.S., Manegold C. i wsp. Gefitinib in combination with gemcitabine and cisplatin in advanced non -small-cell lung cancer: a phase III trial-INTACT 1. J. Clin. Oncol. 2004; 22: 777-784.

117. Herbst R.S., Giaccone G., Schiller J.H. i wsp. Gefitinib in combination with paclitaxel and carboplatin in advanced non -small-cell lung cancer: a phase III trial-INTACT 2. J. Clin. Oncol. 2004; 22: 785-794.

118. Mok T.S., Wu Y.L., Thongprasert S. i wsp. Gefitinib or carboplatin-paclitaxel in pulmonary adenocarcinoma. N. Engl. J. Med. 2009; 361: 947-957.

119. Wu Y.L., Zhou C., Hu C.P. i wsp. LUX-Lung 6: A randomized., open-label, phase III study of afatinib (A) versus gemcitabine/ cisplatin (GC) as first-line treatment for Asian patients (pts) with EGFR mutation-positive (EGFR M+) advanced adenocarcinoma of the lung. J. Clin. Oncol. 2013; 31 (suppl): abstr 8016.

120. Sequist L.V., Yang J.C-H., Yamamoto N. i wsp. Phase III study of afatinib or cisplatin plus pemetrexed in patients with metastatic lung adenocarcinoma with EGFR mutations. J. Clin. Oncol. 2013; 31: 3327-3334.

121. Shepherd F.A., Pereira R.J., Ciuleanu T. i wsp. Erlotinib in previously treated non-small-cell lung cancer. N. Engl. J. Med. 2005; 353: 123-132.

122. Zhu CQ., da Cunha Santos G., Ding K. i wsp. Role of KRAS and EGFR as biomarkers of response to erlotinib in National Cancer Institute of Canada Clinical Trials Group Study BR.21. J. Clin. Oncol. 2008; 26: 4268-4275.

123. Thatcher N., Chang A., Parikh P. i wsp. Gefitinib plus best supportive care in previously treated patients with refractory advanced non-small-cell lung cancer: results from a randomised, placebo-controlled, multicentre study (Iressa Survival Evaluation in Lung Cancer). Lancet 2005; 366: 1527-1537.

124. Kim E.S., Hirsch V., Mok T. i wsp. Gefitinib versus docetaxel in previously treated non-small-cell lung cancer 
(INTEREST): a randomised phase III trial. Lancet 2008; 372: 1809-1818.

125. Douillard J-Y., Shepherd F.A., Hirsch V. i wsp. Molecular predictors of outcome with gefitinib and docetaxel in previously treated non-small-cell lung cancer: data from the randomized phase III INTEREST trial. J. Clin. Oncol. 2010; 28: 744-752.

126. Ciuleanu T., Stelmakh L., Cicenas S. i wsp. Efficacy and safety of erlotinib versus chemotherapy in second-line treatment of patients with advanced, non-small-cell lung cancer with poor prognosis (TITAN): a randomised multicentre, open-label, phase 3 study. Lancet Oncol. 2012; 13: 300-308.

127. Cappuzzo F., Ciuleanu T., Stelmakh L. i wsp. Erlotinib as maintenance treatment in advanced non-small-cell lung cancer: a multicentre, randomised, placebo-controlled phase 3 study. Lancet Oncol. 2010; 11: 521-529.

128. Zhang L., Ma S., Song X. i wsp. Gefitinib versus placebo as maintenance therapy in patients with locally advanced or metastatic non-small-cell lung cancer (INFORM; C-TONG 0804): a multicentre, double-blind randomised phase 3 trial. Lancet Oncol. 2012; 13: 466-575.

129. Johnson B.E., Kabbinavar F., Fahrenbacher L. i wsp. ATLAS: randomized, double-blind, placebo-controlled, phase IIIB trial comparing bevacizumab therapy with or without erlotinib, after completion of chemotherapy, with bevacizumab for first-line treatment of advanced non-small-cell lung cancer. J. Clin. Oncol. 2013; 31: 3926-3934.

130. Pirker R., Pereira JR., Szczesna A. i wsp. FLEX Study Team. Cetuximab plus chemotherapy in patients with advanced non -small-cell lung cancer (FLEX): an open-label randomised phase III trial. Lancet 2009; 373: 1525-1531.

131. Lynch T.J., Patel T., Dreisbach L. i wsp. Cetuximab and first-line taxane/carboplatin chemotherapy in advanced non-smallcell lung cancer: results of the randomized multicenter phase III trial BMS099. J. Clin. Oncol. 2010; 28: 911-917.

132. Kwak E., Bang Y.J., Camidge R. i wsp. Anaplastic lymphoma kinase inhibition in non-small-cell lung cancer. N. Engl. J. Med. 2010; 363: 1693-1703.

133. Shaw AT., Yeap BY., Solomon BJ. i wsp. Effect of crizotinib on overall survival in patients with advanced non-small-cell lung cancer harbouring ALK gene rearrangement: a retrospective analysis Lancet Oncol. 2011; 12: 1004-1012.

134. Shaw AT., Kim DW., Nakagawa K., i wsp. Crizotinib versus chemotherapy in advanced ALK-positive lung cancer. N. Engl. J. Med. 2013; 368: 2385-2394.

135. Seto T., Kiura K., Nishio M. i wsp. CH5424802 (RO5424802) for patients with ALK-rearranged advanced non-small-cell lung cancer (AF-001JP study): a single-arm, open-label, phase 1-2 study. Lancet Oncol. 2013; 14: 590-598.

136. Bergethon K., Show A.T., Ou SHI. i wsp. ROS1 rearrangements define a unique molecular class of lung cancers. J. Clin. Oncol. 2012; 30: 863-870.

137. Sandler A., Gray R., Perry M.C. i wsp. Paclitaxel-carboplatin alone or with bevacizumab for non-small-cell lung cancer. $\mathrm{N}$. Engl. J. Med. 2006; 355: 2542-2550.

138. Reck M., von Pawel J., Zatloukal P. i wsp. Phase III trial of cisplatin plus gemcitabine with either placebo or bevacizumab as first-line therapy for nonsquamous non-small-cell lung cancer: AVAil. J. Clin. Oncol. 2009; 27: 1227-1234.

139. Zinner R., Ross H.J., Weaver R. i wsp. Randomized, open-label phase III study of pemtrexed plus carboplatin (PemC) followed by maintenance pemetrexed versus paclitaxel/carboplatin/bevacizumab (PCB) followed by maintenance bevacizumab in patients with advanced nonsquamous (NS) non-small cell lung cancer (NSCLC). J. Clin. Oncol. 2013; 31 (suppl): abstr. LBA 8003.

140. Socinski A.M., Patel J.D., Garon E.B. i wsp. A phase III study of pemetrexed (Pem) plus carboplatin $(\mathrm{Cb})$ plus bevacizumab (Bev) followed by maintenance pem plus bev versus paclitaxel (Pac) plus cb plus bev followed by maintenance bev in stage IIIb or IV nonsquamous non-small cell lung cancer (NS-N-
SCLC): Overall and age group results. J. Clin. Oncol. 2013; 31 (suppl): abstr. 8004.

141. Barlesi F., Scherpereel A., Rittmeyer A. i wsp. Randomised phase III trial of maintenance bevacizumab with or without pemetrexed after first-line induction with bevacizumab, cisplatin, and pemetrexed in advanced nonsquamous non -small-cell lung cancer: AVAPERL (MO22089). J. Clin. Oncol. 2013; 31: 3004-3011.

142. Sanjaykumar H., Chu D., Shenhong W. Risk of gastrointestinal perforation in patients with cancer treaded with bevacizumab: a metaanalysis. Lancet Oncol. 2009; 10: 559-568.

143. Nalluri S.R., Chu D., Keresztes R. i wsp. Risk of venous thromboembolism with the angiogenesis inhibitor bevacizumab in cancer patients. JAMA 2008; 300: 2277-2285.

144. Soria J.C., Mauguen A., Reck M. i wsp. Systematic review and meta-analysis of randomised., phase II/III trials adding bevacizumab to platinum-based chemotherapy as first-line treatment in patients with advanced non-small-cell lung cancer. Ann. Oncol. 2013; 24: 20-30.

145. Mellemgaard A., Kaiser R., Douillard J.Y. i wsp. Analysis of overall survival in adenocarcinoma NSCLC patients receiving 2nd line combination treatment with nintedanib (BIBF 1120) + docetaxel in the LUME-Lung 1 trial: A randomized, double -blind, placebo-controlled phase 3 study. Eur. J. Cancer 2013; 49 (suppl 2): abstr. 3409.

146. Butts C.A., Socinski MA., Mitchell P. i wsp. START: a phase III study of L-BLP25 cancer immunotherapy for unresectable stage III non-small cell lung cancer. J. Clin. Oncol. 2013; 31 (suppl): abstr. 7500 .

147. Ellis P., Davies AM., Evans WK. i wsp. The use of chemotherapy In patients with advanced malignant pleural mesothelioma: a systematic review and practice guidelines. J. Thorac. Oncol. 2006; 1: 591-601.

148. Muers M.F., Stephens R.J., Fisher P. i wsp. Active symptom control with or without chemotherapy in the treatment of patients with malignant pleural mesothelioma (MS01): a multicentre randomised trial. Lancet 2008; 371: 1685-1694.

149. Vogelzang NJ., Rusthoven JJ., Symanowski J. i wsp. Phase III study of pemetrexed in combination with cisplatin versus cisplatin alone in patients with malignant pleural mesothelioma. J. Clin. Oncol. 2003; 21: 2636-2644.

150. Symanowski J., Rushoven J., Nguyen B. i wsp. Multiple regression analysis of prognostic variables for survival from the phase III study of pemetrexed + cisplatin in malignant pleural mesothelioma. Proc Am Soc Clin Oncol 2003; 22: 647.

151. Jassem J., Ramlau R., Santoro A. i wsp. Pemetrexed plus best supportive care versus best supportive care in previously treated patients with advanced malignant pleural mesothelioma: A randomized phase III trial. J. Clin. Oncol. 2008; 26 : 1698-1704.

152. Zucali PA., Simonelli M., Michetti G. i wsp. Second-line chemotherapy in malignant pleural mesothelioma: results of a retrospective multicenter survey. Lung Cancer 2012; 75: 360-367.

153. Weder W., Stahel R.A., Bernhard J. i wsp. Multicenter trial of neo-adjuvant chemotherapy followed by extrapleural pneumonectomy in malignant pleural mesothelioma. Ann Oncol 2007; 18: 1196-1202.

154. De Perrot M., Feld R., Cho B. i wsp. Trimodality therapy with induction chemotherapy followed bu extrapleural pneumonectomy and adjuvant high-dose hemithoracic radiation for malignant pleural mesothelioma. J. Clin. Oncol. 2009; 27: 1413-1418.

155. Krug L., Pass H., Rusch V. i wsp. Multicenter phase II trial of neoadjuvant pemetrexed plus cisplatin followed by extrapleural pneumonectomy and radiation for malignant pleural mesothelioma. J. Clin. Oncol. 2009; 27: 3007-3013.

156. Bokulbas S., Manegold C., Eberlein M. i wsp. Survival after trimodality therapy for malignant pleural mesothelioma: Radical pleurectomy., chemotherapy with cisplatin/pemetrexed and radiotherapy. Lung Cancer 2011; 71: 75-81. 